\title{
Selection and Application of Microbial Source Tracking Tools For Water-Quality Investigations
}

Chapter 3 of

Section A, Biological Science, of

Book 2, Collection of Environmental Data

Techniques and Methods 2-A3 



\section{Selection and Application of Microbial Source Tracking Tools For Water-Quality Investigations}

By Donald M. Stoeckel

Chapter 3 of

Book 2, Collection of Environmental Data,

Section A, Biological Science

Techniques and Methods Book 2, Chapter A3 


\section{U.S. Department of the Interior \\ Gale A. Norton, Secretary}

\section{U.S. Geological Survey \\ P. Patrick Leahy, Acting Director}

U.S. Geological Survey, Reston, Virginia: 2005

For more information about the USGS and its products:

Telephone: 1-888-ASK-USGS

World Wide Web: http://www.usgs.gov/

Any use of trade, product, or firm names in this publication is for descriptive purposes only and does not imply

endorsement by the U.S. Government.

Although this report is in the public domain, permission must be secured from the individual copyright owners to reproduce any copyrighted materials contained within this report.

Citation:

Stoeckel, D.M., 2005, Selection and application of microbial source tracking tools for water-quality investigations: U.S. Geological Survey Techniques and Methods Book 2, Chapter A3, 43 p. 


\section{Contents}

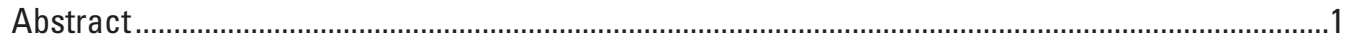

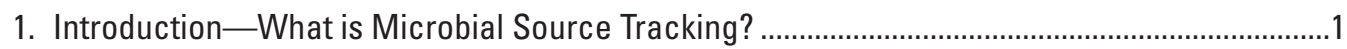

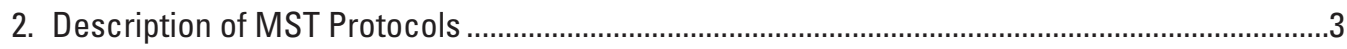

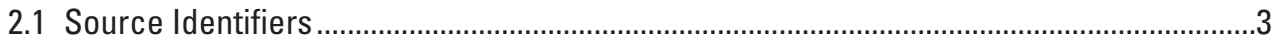

2.2 Detection Methods......................................................................................................

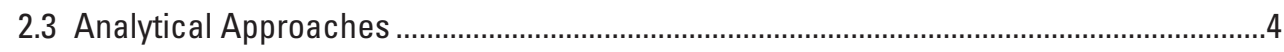

2.3.1 Empirical Matching Approach ............................................................................

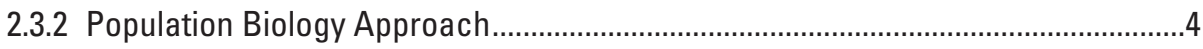

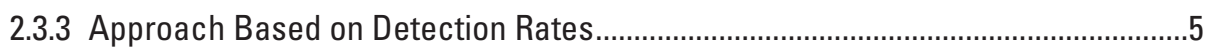

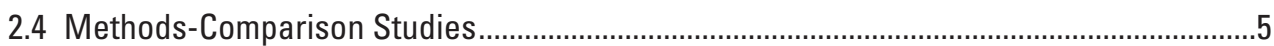

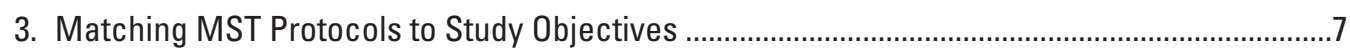

3.1 Single Household Scale—Ohio Septic Leach Field Study ...............................................

3.2 Local Area, Small Population-"Possible Sources of Nitrate in Ground Water at Swine Licensed-Managed Feeding Operations in Oklahoma, 2001" ........................8

3.3 Medium Area, Medium Population-"Patterns and Sources of Fecal Coliform Bacteria in Three Virginia Streams" ........................................................................9

3.4 Medium Area, Transient Population-"Tiered Approach for Identification of a Human Fecal Population Source at a Recreational Beach: Case Study at Avalon Bay, Catalina Island, California" .......................................................................

3.5 Large Area, Large Population-"Sharing of Ribotype Patterns of Escherichia coli Isolates During Baseflow and Stormflow Conditions" ................................................10

4. Assumptions Behind Choice of MST Protocol ..................................................................

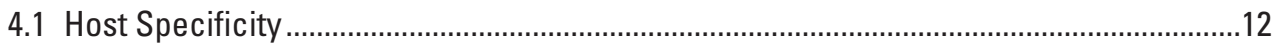

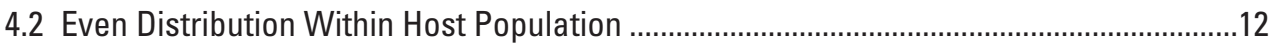

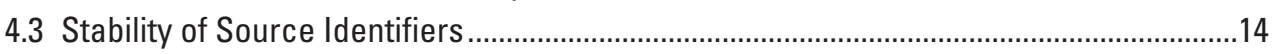

4.3.1 Temporal Stability ........................................................................................ 14

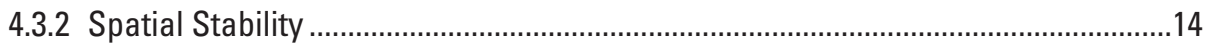

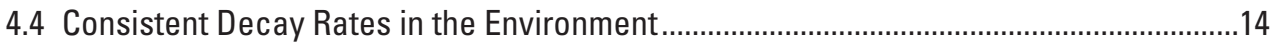

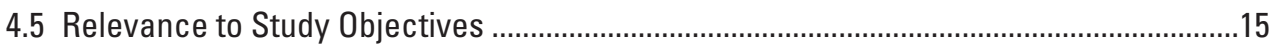

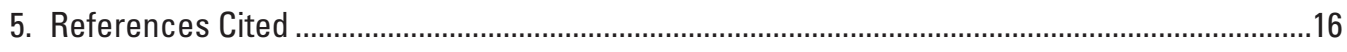

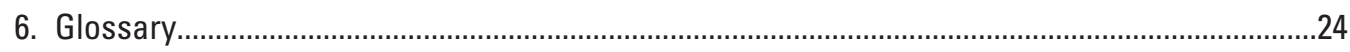

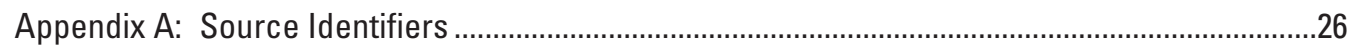

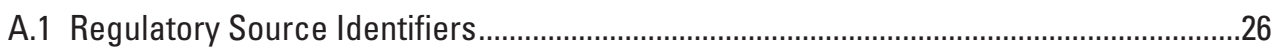

A.2 Nonregulatory Source Identifiers .............................................................................28

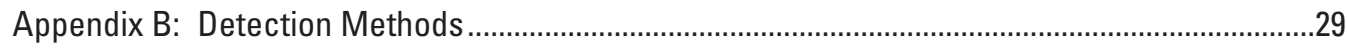

B.1 Conventional Typing Methods ...................................................................................

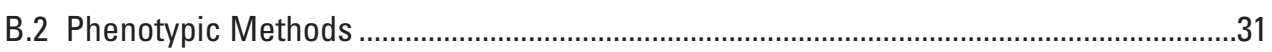

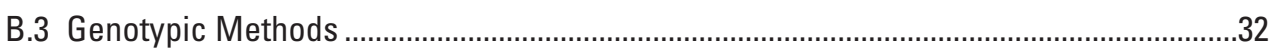




\section{Figure}

1. Decision points in the process of microbial source tracking application, and basic information and decisions that lead to effective use of MST

protocols, sampling designs, and interpretation

\section{Tables}

1. General sources of microbial source tracking information.

2. Summary of how various microbial source tracking (MST) source identifiers meet generalized assumptions of host specificity, distribution among the host population, stability in individual animal hosts, stability in the environment, and relevance to public health regulations or public health risk

\section{Conversion Factors and Abbreviated Water-Quality Units}

\begin{tabular}{lcl}
\hline Multiply & By & To obtain \\
\hline foot $(\mathrm{ft})$ & 0.3048 & meter $(\mathrm{m})$ \\
square mile $\left(\mathrm{mi}^{2}\right)$ & 259.0 & hectare $(\mathrm{ha})$ \\
square mile $\left(\mathrm{mi}^{2}\right)$ & 2.590 & square kilometer $\left(\mathrm{km}^{2}\right)$ \\
gallons per day $(\mathrm{gal} / \mathrm{d})$ & 0.003785 & cubic meter per day $\left(\mathrm{m}^{3} / \mathrm{d}\right)$ \\
\hline
\end{tabular}

Temperature in degrees Celsius $\left({ }^{\circ} \mathrm{C}\right)$ may be converted to degrees Fahrenheit $\left({ }^{\circ} \mathrm{F}\right)$ as follows:

$$
{ }^{\circ} \mathrm{F}=\left(1.8 x^{\circ} \mathrm{C}\right)+32
$$

Concentrations of chemical constituents in water are given either in milligrams per liter (mg/L) or micrograms per liter $(\mu \mathrm{g} / \mathrm{L})$.

Concentrations of bacteria in water are reported in colony-forming units per 100 mililiters (CFU/100 mL), colony-forming units per gram of sampled medium (CFU/g), or cells per gram of sampled medium (cells/g).

Concentrations of phage viruses and enterovirus are reported in plaque-forming units per 100 mililiters (PFU/100 mL). 


\title{
Selection and Application of Microbial Source Tracking Tools for Water-Quality Investigations
}

\author{
By Donald M. Stoeckel
}

\begin{abstract}
Microbial source tracking (MST) is a complex process that includes many decision-making steps. Once a contamination problem has been defined, the potential user of MST tools must thoroughly consider study objectives before deciding upon a source identifier, a detection method, and an analytical approach to apply to the problem. Regardless of which MST protocol is chosen, underlying assumptions can affect the results and interpretation. It is crucial to incorporate tests of those assumptions in the study quality-control plan to help validate results and facilitate interpretation.

Detailed descriptions of MST objectives, protocols, and assumptions are provided in this report to assist in selection and application of MST tools for water-quality investigations. Several case studies illustrate real-world applications of MST protocols over a range of settings, spatial scales, and types of contamination. Technical details of many available source identifiers and detection methods are included as appendixes. By use of this information, researchers should be able to formulate realistic expectations for the information that MST tools can provide and, where possible, successfully execute investigations to characterize sources of fecal contamination to resource waters.
\end{abstract}

\section{Introduction - What is Microbial Source Tracking?}

Many of our Nation's resource waters fail to achieve water-quality standards for designated uses, as required by the Clean Water Act, even after implementation of the National Point-source Discharge Elimination System (NPDES; U.S. Environmental Protection Agency, 2000b). Therefore, contemporary (2005) state water-management plans emphasize control of nonpoint sources of contamination. Difficulty in allocating contributions of various nonpoint sources, however, poses a substantial obstacle to control of contaminant loads. The emerging field of microbial source tracking (MST) may help identify nonpoint sources of fecal contamination. This document describes the science and application of MST to water-quality investigations and identifies current technical and theoretical limitations associated with a variety of MST protocols.

The term "microbial source tracking" refers to a group of analytical protocols used to determine the source of fecal contamination. As evidence, MST uses host-associated characteristics of various microorganisms present in feces; that is, physiological differences in hosts are expected to select for specific characteristics (such as adhesion factors, antibiotic resistance, temperature optima, and other metabolic traits) in associated enteric microorganisms. The MST approach can be thought of as having several key common components and decision points, as illustrated in figure 1. In particular, the protocol used for MST (source identifier, detection method, and analytical approach) must be applicable to the scale and specific objectives of the study. 


\section{Define Problem}

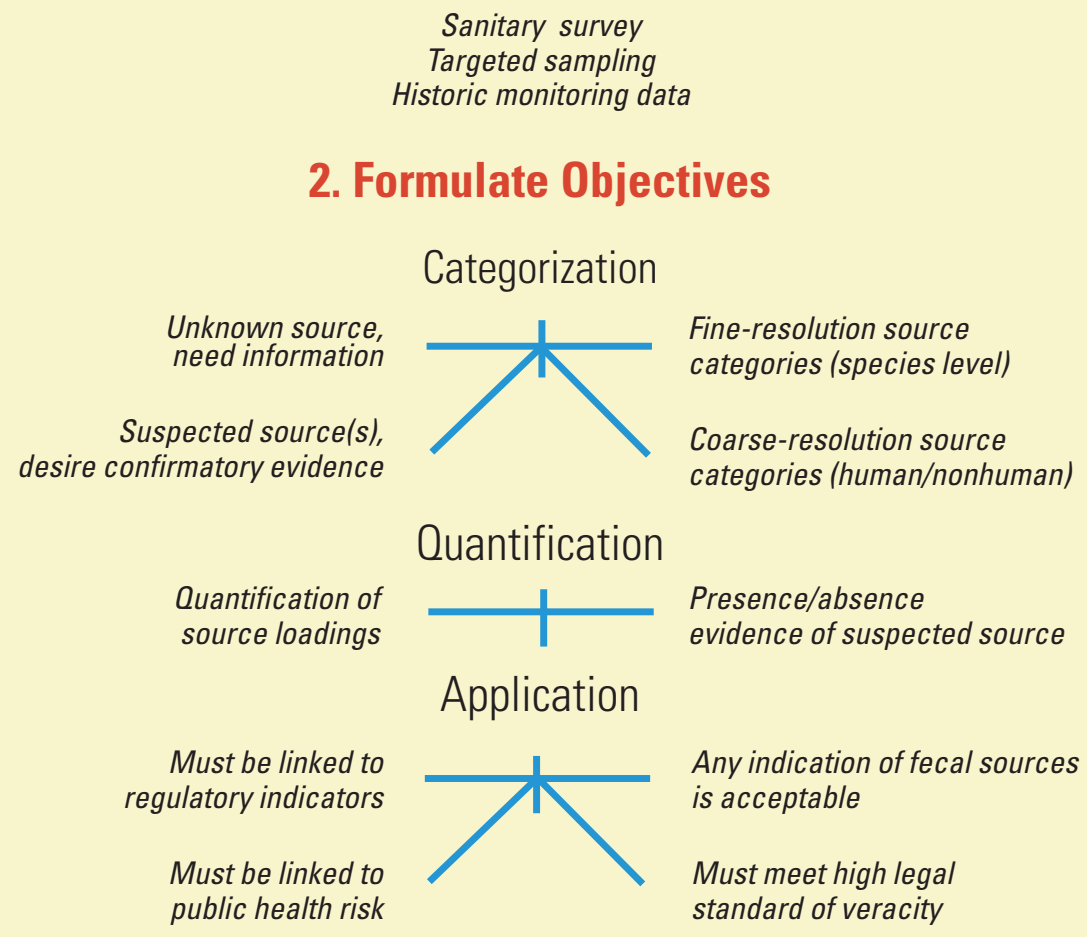

3. Choose MST protocol

4. Define area of relevance and design sampling strategy

\section{Collect and analyze data}

\section{Interpret data}

Figure 1. Decision points in the process of microbial source tracking application, and basic information and decisions that lead to effective use of MST protocols, sampling designs, and interpretation. General sources of information for each decision point can be found in table 1.

Table 1. General sources of microbial source tracking information (MST), by decision point in the MST process.

Topic

References

1. Problem definition

2. Formulation of objectives

3. Choice of protocol

4. Design of sampling strategy

5. Data colection and analysis

6. Interpretation
Ground Water Rule (U.S Environmental Protection Agency, 2000c); Beach guidance, Appendix G (U.S. Environmental Protection Agency, 2002)

This document

This document; Scott and others, 2002; Simpson and others, 2002; Sinton and others, 1998

Protocol for developing pathogen TMDLs (U.S. Environmental Protection Agency, 2001)

Albert and others, 2003; Ritter and others, 2003

Hyer and Moyer, 2004; Long and Plummer, 2004 
For the purposes of this report, a MST protocol is defined by a combination of source identifier, detection method, and analytical approach. Source identifiers are microbiological markers that can be used to discriminate feces from various sources. Examples are Escherichia coli (E. coli) genomic fingerprints, coliphage serotypes, and markers within a $16 \mathrm{~S}$ rRNA gene carried by Bacteroidetes. Detection methods are laboratory methods used to detect or distinguish among source identifiers. Examples are antibiotic resistance analysis and ribotyping to distinguish $E$. coli types, traditional serotyping and line-blot hybridization to distinguish coliphage types, and length heterogeneity polymerase chain reaction (PCR) or terminal restriction fragment length polymorphism analysis to detect host-associated $\mathrm{Bac}$ teroidetes markers. Analytical approaches are strategies used to classify contamination in test samples by comparison to known-source fecal reference materials. Examples are direct matching of subtypes and clustering by fecal source.

Many MST protocols are available for research or practical application. None of the protocols, however, is completely accurate, nor is any one protocol universally applicable to all objectives. This report describes several prior applications of MST and presents information intended to assist in selection of appropriate MST protocols to meet design objectives of water-quality investigations. Information about formulation of objectives and choice of protocol is presented in the context of the framework portrayed in figure 1, but the other MST decision points from figure 1 are not discussed at length in this report. Other sources of information about each MST decision point are listed in table 1.

\section{Description of MST Protocols}

MST protocols are made up of three interrelated parts—a source identifier, a detection method, and an analytical approach:

- Source identifiers are the microbiological targets (that is, viruses, bacteria, or protozoa) on which the MST study is based. Examples are genotypes or phenotypes of E. coli, genotypes of F-specific RNA-based coliphage, and host-specific markers found in Bacteroides/Prevotella bacteria. (See Appendix A for detailed descriptions.)

- Detection methods are the techniques (generation of genotypic or phenotypic profiles, detection of molecular markers) used to recognize source identifiers from various sources. Examples are ribotyping, antibiotic resistance analysis, length-heterogeneity polymerase chain reaction (LH-PCR), or hybridization with host-specific sequences. (See appendix B for detailed descriptions.)

- Analytical approaches are the conceptual frameworks used to link results from water samples to fecal sources. Examples are library-dependent approaches (epidemiological matching, population biology clustering) and library-independent approaches (based on detection of host-specific markers). A library, in the context of MST, is an extensive collection of source identifiers (often bacterial isolates) that represents fecal material from a source.

\section{$2.1 \quad$ Source Identifiers}

The choice of source identifier depends, in part, on the objectives of the work. For example, MST in support of recreational water-quality objectives (such as total maximum daily load (TMDL) plans) frequently uses regulated indicator microorganisms as source identifiers. The U.S. Environmental Protection Agency (USEPA) has promulgated regulatory criteria for E. coli and enterococci concentrations in recreational waters (Dufour, 1984), and for total coliform and coliphage (proposed) presence as a measure of drinking-water quality (U.S. Environmental Protection Agency, 2000c). Similarly, the U.S. Food and Drug Administration uses fecal coliform concentrations as a regulatory measure of shellfish-harvesting water quality (U.S. Food and Drug Administration, 2003). Nonregulatory source identifiers, such 
as Bacteroidetes, are used sometimes to confirm fecal sources when a sanitary survey is ambiguous. Alternately, nonregulatory source identifiers sometimes are used on the basis that any reduction in feces from detected sources (based on evidence from nonregulatory source identifiers) will reduce concentrations of regulatory fecal-indicator microorganisms. Descriptions of many available source identifiers are provided in Appendix A.

\subsection{Detection Methods}

Choice of detection method depends on the source identifier chosen, the objectives of the study, and the availability of analytical capabilities. Detection methods that have been developed and used for MST range from the conventional (based on host-associated species such as Enterococcus faecalis; Wheeler and others, 2002) through various typing methods of individual isolates (phenotypic or genotypic profiling). A new generation of MST methods based on detection of host-specific gene sequences from whole-water extracted DNA is under development (Field and others, 2003). Descriptions of many available detection methods are provided in Appendix B.

\subsection{Analytical Approaches}

A basic division in analytical approaches for library-dependent MST is between epidemiology and population biology. Epidemiology hypothesizes that specific microbial subtypes are present predominantly in one host category, whereas population biology hypothesizes that a more general combination of traits is common to source identifiers from a host category (such as antibiotic resistance patterns among the human population). A large number of cultivated reference isolates must be collected in the same time and space as the test samples to support classification by library-dependent approaches.

In contrast to library-dependent MST, inferred presence of a fecal source by library-independent MST is based on detection of (generally) a single host-associated marker. Presence of a single trait is anticipated among all or many individuals in a host category, and the trait is expected to be absent in individuals from other host categories. In the library-independent approach, reference feces samples must be collected to develop and validate the method, but the reference sample requirement from the same time and space as the test samples is dictated solely by quality-control needs.

\subsubsection{Empirical Matching Approach}

The empirical matching approach is often referred to as one-to-one matching within library-dependent MST. In this approach, each individual source identifier isolate is assigned to a type. Most types are expected to be exclusive to broad or narrow host categories, regardless of a functional basis describing why that type would be specific to a host category. A functional basis, which may indicate a host-microbe interaction that would support the hypothesis of host specificity, may be used to support the host specificity implied by empirical pattern matching, but it is not necessary: simple detection is sufficient. Epidemiologists use a wide variety of typing methods in an attempt to define useful microbial types in applications related to MST. (See Appendix B for details.) The most discriminating typing methods can separate even closely related lineages into defined types. Types are defined and tested for specificity to a host to allow association of unknown isolates with sources (Hyer and Moyer, 2003; Samadpour and Chechowitz, 1995).

\subsubsection{Population Biology Approach}

The population-biology-based approach can also be library dependent; users of this approach assume an underlying distribution of host-specific characteristics in enteric microorganisms. These characteristics could arise, for instance, during coevolution with specific 
hosts (Gordon, 2001; Souza and others, 1999) and result in competitive advantage for specific strains in their coevolved hosts. For source tracking by use of a population biology model, it is assumed that functional characteristics such as phenotypes based on carbon utilization capability (Hagedorn and others, 2003) or sensitivity to antibiotics (Whitlock and others, 2002; Wiggins, 1996) can be used to generate rules to associate bacterial isolates with hosts. Genetic similarity measures, when used in library-dependent approaches, generally are not linked to a specific functional gene. In some experiments, however, functional-gene sequences have been used to define genotypes (Ram and others, 2004; Guan and others, 2002).

Because bacteria reproduce asexually yet often share genetic material, microbial population geneticists look at bacterial genes as a continuum of information in which "species" are nodes that represent stable combinations of genes. Within a species, finer-scale characteristics that may be advantageous within specific hosts are passed down through clonal succession. Statistical group separation methods, such as discriminant analysis, are used to identify combinations of characteristics that are found more commonly in one host over another (Harwood and others, 2000; Parveen and others, 1999; Wiggins, 1996).

\subsubsection{Approach Based on Detection Rates}

Interpretation of results from library-independent approaches is similar to the matching-type library-dependent approaches-a characteristic is either detected or not detected in a DNA extract. Methodological advances with quantitative PCR are showing some promise for quantitation of host-specific markers (Dick and Field, 2004; Seurinck and others, 2005); otherwise, frequency of detection or most-probable-numbers style analysis are the only ways to infer that feces from a particular host are dominant or not dominant. This approach is also different from the cultivation-based library-dependent approaches because (1) DNA contained in a large volume of water often has to be efficiently extracted because most of these methods are cultivation-independent, (2) extracted DNA has to be purified so that PCR-based detection can be done effectively, and (3) none of the source identifiers used in library-independent protocols have been directly correlated with concentrations of regulated fecal indicator microorganisms.

\subsection{Methods-Comparison Studies}

Many protocols are available for MST research. (See Appendixes A and B.) Two efforts to compare various protocols and approaches have been completed. A USGS-led study compared analytical protocols, all of which utilized a library-dependent, E. coli-based approach (Stoeckel and others, 2004). A USEPA-funded study led by the Southern California Coastal Water

Research Project (SCCWRP) compared protocols utilizing a variety of approaches. The results of the USEPA study were published as a series of reports (see Griffith and others, 2003, for summary and other references).

In both studies, various researchers used MST protocols to determine whether they could correctly associate challenge known-source material with the correct host. In the USGS study, the same 630-isolate library of $E$. coli collected from animals in Berkeley County, W.Va., was distributed to each researcher for evaluation. The known-source library was used to classify isolates from a separate challenge collection of 200 isolates. The challenge isolates were collected from the same area but from different individual animals.

In the USEPA study, a collection of 36 reference feces samples (rather than isolates) and 8 reference composite waste samples was distributed to each researcher for characterization. Twelve challenge slurries were made from the reference materials, representing one to three sources. The USEPA study tested a broader range of MST protocols than the USGS study and, unlike the USGS study, full representation of the source population was achieved because the very same fecal reference materials added to test slurries were previously characterized by each researcher. Because feces—not isolates—were used as reference material, a variety of library- 
dependent and library-independent methods could be compared with one another (Griffith and others, 2003).

The USGS study pointed out some limitations of protocols used in library-dependent, $E$. coli-based approaches to MST (Stoeckel and others, 2004). The evaluated protocols represented techniques often used for this type of MST at the time of the study (2001 to 2002):

- Antibiotic resistance analysis (ARA)

- Carbon utilization profiles

- Repetitive DNA element polymerase chain reaction (rep-PCR):

- REP primer pair

- Box A1R primer

- Ribotyping:

- HindIII restriction enzyme

- EcoR1 and $P v u I I$ restriction enzymes

- Macrorestriction using NotI restriction enzyme, separated by pulsed-field gel electrophoresis

The seven protocols were evaluated for their ability to

- reproducibly generate data for a given $E$. coli isolate and

- accurately classify E. coli isolates to their hosts of origin:

- eight-way classification to host species,

- three-way classification to management categories of human, domestic animals, and wildlife, and

- two-way classification to human or nonhuman.

Of the seven protocols evaluated, only pulsed-field gel electrophoresis was able to correctly classify all replicates, a group of challenge isolates subcultured from the known-source library. The other protocols classified fewer than 60 percent of replicates to the correct host species. Failure to correctly classify replicates indicated that either $E$. coli isolates in the known-source library lacked host specificity or tested protocols lacked precision.

When accuracy was evaluated, a clear tradeoff between correctness and completeness of classification was evident. One protocol correctly classified 90 percent (to species) of the 6 percent attempted; typical of other results was the protocol that correctly classified 27 percent (to species) of the 100 percent attempted. For the two-way classification, four protocols were 63-100 percent accurate when attempting classification of 6-100 percent of the isolates, but accuracy for three protocols was not significantly different from random classification to two sources (50 percent). These accuracy results indicated that tracking isolates to source categories may fail when, as in this study, feces from only a few individuals are used to characterize a much larger population (in this study, 20 humans from a population of 80,000). Failure was evident as both false classification and inability to classify many challenge isolates.

A fundamental conclusion of the USEPA study was that all current approaches to MST have both strengths and weaknesses. Library-dependent methods had low false-positive detection rates, indicating that they would best be applied in settings when large populations of individuals are expected to contribute fecal contamination (Field and others, 2003). One weakness of library-independent methods, however, is that the source identifier may not be present in the feces of most individuals (for example, viruses and E. coli toxin genes; see Appendix A for descriptions). This absence of the source identifier would lead to false-negative results. When applied in a setting with large populations, these methods would be expected to have a lower false-negative rate. Library-dependent methods, on the other hand, had low false-negative detection rates, in part because they tended to detect all sources in all samples. This tendency led to high false-positive rates that could be reduced by establishing "minimum detectable threshold" criteria to aid interpretation (Harwood and others, 2003; Myoda and others, 2003; Ritter and others, 2003). Setting a minimum detectable threshold involves estimation of classification error, then rejecting detection rates that are less than that classification error. This allows the 
researcher to report only sources that are more certain to have contributed fecal contamination to the sample and to reject the uncertain ones.

Although every researcher had samples of all materials used to make the test samples, no method was completely accurate for all sources. Griffith and others (2003) concluded that length heterogeneity PCR, using markers for Bacteroidetes (see Appendix A, sec. A.2.4.1 and Appendix B, sec. B.3.3.2), had the lowest error rates of all protocols tested. This protocol is limited in the number of sources for which markers have been developed (human and ruminant) and the current lack of ability to quantify the detected sources. Library-dependent methods, though more prone to error, may be able to detect the presence of each source and to estimate relative contribution by each source. The results of the USEPA study, however, indicated that library-dependent methods as currently applied often assigned a large proportion of isolates to an "unknown" category, and there was no reliable relation between proportion of bacteria associated with each host and the known composition of the samples (Ritter and others, 2003).

\section{Matching MST Protocols to Study Objectives}

MST can be used to address a variety of objectives related to impacts of feces released to the environment. The following examples illustrate just a few of the ways in which MST protocols have been applied at various scales. This discussion is not intended to be a comprehensive review of past application of MST protocols, nor should these examples necessarily be taken as models of how MST should be applied. Following the description of each study is a brief discussion of alternative protocols that might have been applied to the problem.

\subsection{Single-Household Scale-Ohio Septic Leach Field Study}

Ohio's state guidelines for siting leach lines for household sewage-treatment system (septic systems) leach lines are based on the assumption that treatment of pathogens occurs within the first $2 \mathrm{ft}$ of soil and treatment of nutrients occurs within the first $4 \mathrm{ft}$ of soil (Duncan and others, 1994; Mancl and Slater, 2002). Curtain drains, where constructed to lower the local water table underlying a leach field, often are installed $10 \mathrm{ft}$ from the leach line in Ohio. The hypothesis evaluated in this study was that septic systems installed in Ohio soils with a shallow depth to a limiting condition (the limiting condition often is a high water table or bedrock) provide sufficient treatment of waste. This hypothesis was tested by analyzing near-surface ground water collected by curtain drains and in piezometers at various distances from selected septic leach fields. E. coli were detected at horizontal distances of 4-20 ft from the septic leach line at a shallow depth range (4-8 ft), but not in deeper soil water. E. coli also were detected in one of two tested curtain-drain effluents.

The area of inference and source populations in this study were both strictly limited; thus, the approach used in this study was to detect direct matches between $E$. coli cultivated from potential sources and $E$. coli cultivated from contaminated water. There was no underlying assumption that $E$. coli genotypes were host-specific; rather, it was hypothesized (and tested) that human and alternate host populations did not carry the same genotypes. MST data were supplemented in this study by collection of nitrogen and oxygen stable-isotopes ratios, wastewater-organic-compound concentrations, and chloride concentrations (Dumouchelle and Stoeckel, 2005).

The objective of MST in this study was to determine whether $E$. coli were present in nearsurface ground water and curtain-drain effluent. When present, E. coli were tested to determine whether types detected in ground water were the same as those detected in a particular septic system. The physical proximity of the sample water to the septic system makes support of this hypothesis likely, but $E$. coli could also come from droppings on the land surface (pets) or from widespread contamination of offsite, near-surface soil water. Populations of likely contributing hosts were small, consisting of a single family for the septic system and a few pets or wildlife for surface deposits. Contributing hosts were fully represented (household) or heavily represented (local outdoor pets and wildlife) in the known-source library. Widespread contamination of off- 
site, near-surface soil water would be detected by observation of $E$. coli in water samples distant from the septic system. E. coli isolates were characterized by use of a rep-PCR protocol (see Appendix B, sec. B.3.1.3) similar to that used by Dombek and others (2000).

By use of MST tools (rep-PCR typing of cultivated E. coli), not only were E. coli detected in near-surface ground water, but the probable source of the contamination was indicated. Without the use of $E$. coli typing, it would have been possible to claim that the $E$. coli found in curtain drain effluent and other near-surface ground water samples came from surface scat, not from the septic system. Indeed, in one case where $E$. coli were detected at great distance ( $20 \mathrm{ft}$ ) from the leach field, E. coli typing indicated that the probable source of those E. coli was dog feces at the land surface rather than the septic leach field.

Most, if not all, available $E$. coli typing methods probably would have served the same purpose as rep-PCR in this case (van Belkum and others, 2001). Typing of enterococci probably also would have been sufficient to accomplish the objectives of this study. The low diversity of F-specific coliphage (only four types) would have limited its utility for this specific purpose; however, if found, F-specific coliphage and other library-independent markers may have been useful to indicate whether fecal contamination was of human or nonhuman origin. Dye tracers and wastewater organics would be sufficient in this setting to demonstrate a hydrologic link but could not demonstrate subsurface transport of particulates such as $E$. coli nor exclude other origins of $E$. coli detected at a distance from the septic leach field.

\subsection{Local Area, Small Population-“"Possible Sources of Nitrate in Ground Water at Swine Licensed-Managed Feeding Operations in Oklahoma, 2001"}

The Oklahoma Department of Agriculture, Food, and Forestry collected ground-water samples underlying swine confined-animal feeding operations (CAFOs). Nitrate concentrations exceeding $10 \mathrm{mg} / \mathrm{L}$ as $\mathrm{N}$ were detected in 79 wells near 35 CAFOs. The nitrate Maximum Contaminant Level (MCL) for drinking source water is $10 \mathrm{mg} / \mathrm{L}$ (U.S. Environmental Protection Agency, 1996). Waste from the CAFOs was treated in waste-stabilization lagoons, and each lagoon contained high concentrations of nitrogen. Nitrate concentrations have been measured as high as $300 \mathrm{mg} / \mathrm{L}$ in swine waste-stabilization lagoons (cited in Becker and others, 2003). The hypothesis tested in this study was that nitrate-enriched water leaks from waste-stabilization lagoons and may contribute nitrate to nearby ground water. Support of this hypothesis required some test for subsurface flow between the lagoon and contaminated ground water through the lagoon liner.

MST was applied in this study to determine whether the types of E. coli in monitoring wells were the same as those in the adjacent waste-stabilization lagoon. Detection of the same types would provide evidence that $E$. coli traveled from the lagoon to the monitoring well and would support the hypothesis of a hydrologic link between the monitoring well and the lagoon. The objective was addressed by a design in which genotypes of $E$. coli in monitoring wells were compared with genotypes of $E$. coli in the associated swine lagoons. MST data were supplemented in this study by collection of data on surrounding land use, nitrogen stable-isotope ratios, and organic wastewater compound concentrations. E. coli collected in this study were analyzed by ribotyping at the Institute for Environmental Health by the protocol reported in Hyer and Moyer (2003; see Appendix B, sec. B.2.3.1). Selected isolates also were analyzed at the USGS Ohio Water Microbiology Laboratory (Columbus, Ohio) with a rep-PCR protocol similar to that reported by Dombek and others (2000; see also Appendix B, sec. B.3.1.3).

Fecal coliform concentrations in the lagoons were highly variable (16 to 210,000 CFU/100 $\mathrm{mL}$ ), and E. coli were detected in 6 of 79 monitoring wells. Of the six wells where $E$. coli were detected, ribotyping characteristics indicated a swine source in five. Additional sources (human, avian, deer) were indicated in two of the five. The sixth had indications of deer as the primary source of fecal contamination (Becker and others, 2003). Additional evidence was collected by an alternate method (rep-PCR) for a well at which E. coli were detected ${ }^{1}$ and its associated lagoon (data not reported in Becker and others, 2003). The well sample contained E. coli that

${ }^{1}$ Referred to as well 360618098024501 in Becker and others (2003). 
were indistinguishable, by rep-PCR banding patterns, from E. coli in the lagoon. This evidence supported the interpretation based on ribotyping that swine were a source of $E$. coli to that well. The well also yielded water with a nitrate concentration $(37 \mathrm{mg} / \mathrm{L})$ above the MCL of $10 \mathrm{mg} / \mathrm{L}$ but with no detections of animal-waste-associated wastewater compounds (Becker and others, 2003).

As with the first study (section 3.1), this study required that enough different types of $E$. coli could be detected that a match with a type from the swine lagoon was strong evidence that the swine lagoon was the source of the fecal contamination. Many typing protocols could have been used to accomplish this purpose (see Appendix B); alternatively, enterococci could have been used as the indicator of fecal contamination (see Appendix A). An additional alternative approach would have been to search for swine-specific markers (such as the swine-specific toxin gene of E. coli; see appendix B, sec. B.3.3.2) in the monitoring wells, or to establish a hydrologic link between the lagoon and the monitoring well by use of dyes, detection of swine-associated fecal compounds, or other strategies.

\subsection{Medium Area, Medium Population-“Patterns and Sources of Fecal Coliform Bacteria in Three Virginia Streams"}

The objective of the study was to demonstrate field applicability of a MST approach and to identify the sources of fecal coliforms in the study streams (Hyer and Moyer, 2003). In general, the potential sources of fecal contamination in each watershed were considered to be humans, pets, domestic livestock and poultry, migratory birds, or other wildlife. Increased effort toward control of any one of the listed management categories by resource managers, without appropriate supporting data, likely would be contentious to the local government, the agricultural community, or the general public.

This study illustrates a different approach from the Ohio septic system study or the repPCR part of the Oklahoma swine lagoon study. Reseachers in the Ohio and Oklahoma studies attempted to compare a source population of E. coli (septic tank and swine lagoon, respectively) with the E. coli found in contaminated water. The specific identification of host was not attempted in those studies. Specific identification of host, as was done in the Virginia study, goes beyond "this was found both here and there, so there may be a link" to "wherever it is found, this E. coli type is associated with a specific host." The assumptions implicit in this approach are the main points of discussion in the chapter on assumptions underlying application of MST (chapter 4).

Many streams in Virginia do not meet applicable designated-use criteria because of microbiological impairment, despite control of known point sources of fecal contamination. Three streams were chosen for evaluation in the reported study: Accotink Creek, drainage area $25 \mathrm{mi}^{2}$, human population greater than 110,000, primarily urban; Blacks Run, drainage area $20 \mathrm{mi}^{2}$, human population about 34,700, mixed urban and agricultural; Christians Creek, drainage area $107 \mathrm{mi}^{2}$, human population about 12,000, primarily agricultural. Extensive base-flow, eventflow, and synoptic sampling was done in each watershed over 20 months. MST by ribotyping (Appendix B, sec. B.3.2.1) was done on E. coli isolates collected at a state-determined waterquality compliance point for each watershed. The known-source E. coli reference collection of Dr. Mansour Samadpour (Institute for Environmental Health, Seattle, Wash.; more than 50,000 isolates at the time) was used and supplemented by known-source acquisitions in the studied watersheds. The hypothesis in this study was that ribotypes (strains) of E. coli are specific to host species; therefore, any stream-isolated $E$. coli with a ribotype that matched a known-source isolate could be assigned to that host species as the source.

Multiple lines of evidence were used to evaluate expectations for MST findings in these study streams. The authors began by evaluating populations and distributions of fecal sources in each watershed. Synoptic sampling was done to evaluate longitudinal trends in fecal-indicator concentrations in the main stem, in tributaries, and in effluents discharged to the main stem. Seasonal and flow-related trends in fecal-indicator concentrations also were evaluated. These data were interpreted in the context of transport pathways and animal distributions in the watersheds to indicate expected sources of fecal-indicator bacteria. 
The MST results were a combination of the expected and the unexpected. Ribotype matching of fecal-indicator bacteria in Accotink Creek, the urban setting, indicated contributions by human and pet feces, as expected, but also a strong influence by waterfowl. Blacks Run fecalindicator bacteria were of mixed sources (human, pet, and livestock) as expected. Fecal-indicator concentrations in Christians Creek had a larger human and pet component than expected for a primarily agricultural watershed (about 25 percent of isolates), compared with livestock and poultry (about 50 percent). A further unexpected finding in all three watersheds was that relative contributions from each major source were about the same during base-flow and stormflow periods, despite the expectation that different transport pathways would dramatically change relative contributions from different sources. Lastly, the study documented seasonal patterns in the contributions of bacteria from cattle and poultry sources in Blacks Run and Christians Creek; this seasonal pattern was consistent with the land-management strategies used in each watershed.

Several supporting elements were included to help interpret MST data in this study. The unexpectedly high contribution by waterfowl in the urban Accotink Creek watershed was supported by the results of a prior study in a neighboring urban watershed, Four Mile Run (Simmons and others, 2000). Contributions of bacteria from human sources were independently supported by detection of organic wastewater compounds. (Detectable concentrations of caffeine and cotinine were present in all three streams.) Detection of seasonal variability of poultry waste inputs to Christians Creek was supported by trends in total arsenic data collected by Hancock and others (2000). The poultry-feed amendment Roxarsone contains arsenic that is generally excreted by the birds, and the poultry litter eventually is applied to the surrounding agricultural fields. Total arsenic concentrations increased during storm runoff, supporting the hypothesis that field-applied poultry litter was flushed into streams.

Ribotyping of E. coli is one of several currently (2005) available approaches that could address the objectives of this study. Because of the size of the watershed (and the large contributing populations of sources), use of any library-dependent method would require a very large library of known-source bacteria (Wiggins and others, 2003; Yang and others, 2004). Because the data were used for development of TMDL plans, numerical approximations of contribution by each source was required; thus, library-independent methods would have been less appropriate to meet the goals of this study. One labor-intensive alternative would have been to conduct more intensive sampling of both flow and concentration in the streams and to calculate the load from each source on the basis of known population contributing to many small subdrainages.

\subsection{Medium Area, Transient Population-“'Tiered Approach for Identification of a Human Fecal Pollution Source at a Recreational Beach: Case Study at Avalon Bay, Catalina Island, California"}

Avalon Bay is a tourist destination on Catalina Island, Calif. Boehm and others (2003) report that 17,500 tourists arrive on a typical summer-season day at the town of Avalon, population 3,500. At the time of the study, the beach was closed if any one of seven water-quality criteria was exceeded (single-sample or geometric-mean concentrations of total coliforms, fecal coliforms, or enterococci, plus the ratio of total coliform to fecal coliform concentrations). The authors report that in the summers of 2000 and 2001, the beach was commonly closed because of single-sample enterococci concentrations. The source of enterococci was not obvious. The community is sewered with trunk lines parallel to the beach at a distance of $20 \mathrm{~m}$ from the shoreline, and the wastewater-treatment plant outfall $\left(2,200 \mathrm{~m}^{3} / \mathrm{d}\right)$ is southeast of Avalon Bay, $100 \mathrm{~m}$ from the shore and $65 \mathrm{~m}$ deep. Other potential sources of fecal contamination include "nuisance water" from street cleaning and seabirds. The sewage collection systems of the 400 or so boats in the harbor are controlled by a dye program that limits the potential for undetected direct discharge by these vessels.

The authors of this study (Boehm and others, 2003) proposed an approach that combines intensive monitoring of fecal-indicator bacteria concentrations, observation of local hydrology and potential sources, and qualitative testing for presence of fecal material from specific sources to understand a particular contamination problem. This is one of the few published reports in which a library-independent, cultivation-independent protocol was applied to an environmental 
setting. The researchers in this study used a combination of intensive sampling (similar to the targeted sampling approach proposed in Kuntz and others, 2003), a comprehensive sanitary survey that included sampling potential sources for fecal-indicator bacteria concentrations, and testing for human-specific genetic markers contained in Bacteroidetes (Bernhard and Field, 2000b) and human-specific enterovirus (Monpoeho and others, 2000).

The objective of MST in this study was to evaluate whether human feces contributed to water-quality-standard exceedances in Avalon Bay. The tiered approach described in the report was composed of three parts. First was a survey of contamination patterns, which, in conjunction with local hydrology, showed that contamination came from a localized nearshore source (effectively ruling out the wastewater-treatment-plant discharge as a source). Second was a survey of potential sources, in which a broken pipe that released fecal-indicator bacteria was found and subsurface beach water, nuisance water from street cleaning, and seabird droppings all were shown to carry high concentrations of fecal-indicator bacteria. A nonpermitted discharge pipe and boat cooling-water discharge were shown to carry negligible concentrations of fecal-indicator bacteria. The third and final step was to apply two library-independent tests (Bacteroidetes human-specific marker and human-specific enterovirus) to various water samples. Though human-specific markers were detected in both subsurface beach water and Avalon Bay water, the incidence of human-specific marker detection was not related to exceedance of the waterquality standards in the bay. Thus, although presence of human fecal material was detected in one source of high fecal-indicator bacteria, the relative contribution of that source and other sources of fecal-indicator bacteria to water-quality-standard exceedances in Avalon Bay remains unknown.

The objective of the reported study was to detect whether human-origin fecal material was present in Avalon Bay. By use of the approach described, the authors were able to detect fecal material of human origin in Avalon Bay-also indicated were that (1) one hydrologic pathway for that fecal material was by way of subsurface transport under the beach (recall that the sewage system trunk line runs $20 \mathrm{~m}$ from the shoreline), and that (2) the wastewater-treatment-plant outfall probably did not contribute fecal material of human origins to Avalon Bay. Had quantification of contributions been a requirement, the researchers may have chosen more expensive alternatives of calculating loads from each source to support a model for bay water quality or applying a library-dependent method in an attempt to classify the source of each colony-forming unit of fecal-indicator bacteria. Library-dependent methods would, however, be almost certain to fail in this setting because of the transience of the tourist population (17,500 different people every day).

\subsection{Large Area, Large Population-“'Sharing of Ribotype Patterns of Escherichia coli Isolates During Baseflow and Stormflow Conditions"}

The upper Chattahoochee River flows through the city of Atlanta, Ga. Many reaches in the watershed in and around Atlanta do not meet water-quality standards for fecal-coliform bacteria concentrations. A study was designed to evaluate differences in E. coli detected during base flow and stormflow as a means of indicating management strategies to control fecal-coliform contamination in the study area. The hypothesis tested in the study was that distinct $E$. coli genotypes could be detected at sample sites during base flow in contrast to those detected during stormflow.

The objective of the study was to test the spatial and flow-related variability in $E$. coli genotypes. E. coli were differentiated by ribotyping by the protocol described in Hartel and others (2004), which is very similar to that used in the Oklahoma (Becker and others, 2003) and Virginia studies (Hyer and Moyer, 2003) described in sections 3.2 and 3.3. (See Appendix B, sec. B.3.2.1.)

This study demonstrated high diversity in E. coli ribotypes found in a watershed with many tributary streams and outfalls, a large catchment area, and large populations of people and other animals in an urban setting. From a collection of 262 isolates ribotyped, 163 distinct patterns were detected. Only 21 isolates ( 8 percent) were multiple detections of the same ribotype (6 ribotypes were detected multiple times). Because there were so many singleton detections 
of ribotypes (only detected once during the study), the opportunity to characterize patterns in ribotype pattern occurrence with flow regime was very limited. It was apparent from this study that enormous sampling effort, particularly for a known-source library, would be necessary to do library-dependent MST in a system as complex as the Chattahoochee River watershed. An alternative approach in this setting might be to narrow the scope of the study area by use of targeted sampling (Kuntz and others, 2003) or to use some of the emerging library-independent PCR-based markers in a most-probable-numbers dilution series format to estimate the relative contributions by various sources in the watershed. (See appendix B, sec. B.3.3.)

\section{Assumptions Behind Choice of MST Protocol}

A comprehensive objective of MST studies is quantitative assessment of all fecal or fecal-indicator loads from multiple source categories affecting regulatory or other public health standards for water quality at a sample site. Reliable attainment of this objective is constrained by the following assumptions:

- Host specificity. The source identifier(s) is associated exclusively with a single host species or other grouping. There is no alternate source of the source identifier(s).

- Even distribution within host population. The source identifier(s) is found in every individual of the host population at the same concentration.

- Stability of source identifiers. The source identifier(s) is invariable on the spatial and temporal scale of the study's area of inference.

- Consistent decay rate in the environment. The source identifier(s) for each host category decays at the same rate and does not replicate outside of the host.

- Relevance to study objectives. The chosen source identifier(s) is amenable to specific objectives of the investigation, such as reduction of regulatory fecal-indicator bacteria concentrations or verifiable reduction in public health risk.

No MST protocol meets all of these assumptions (table 2 at back of report), nor do the objectives of every MST study require that each assumption be met. Choice of MST protocol is driven, in part, by the importance of each assumption to meeting the objective of the study and the degree to which the MST protocol meets each assumption.

\subsection{Host Specificity}

Host specificity is expected to be highest for microorganisms that coevolved with their hosts. The textbook examples of this type of host-specific association are symbioses, like the relationship in which the bacterium Vibrio fischeri produces light in a special organ under the eyes of the flashlight fish (Photoblepharon palpebratus) and the relationship in which bacteria of the species Rhizobium nodulate the roots of leguminous plants for nitrogen fixation (Atlas and Bartha, 1993). Examples of host-specific relationships more relevant to MST include pathogenic viruses, which must be able to recognize the correct host cell for infection. There is no expectation of strong host specificity for a microorganism that does not have a functional interaction with its host.

The regulatory fecal indicators E. coli, total and fecal coliforms, coliphage, and enterococci are examples of MST source identifiers that make up a small proportion of the enteric biota and have little or no functional interaction with their hosts. The widely studied species $E$. coli is considered to be an opportunist that has limited specificity for its enteric environment and, in warmblooded hosts, can be found in other body systems (such as urethra, causing urinary tract infections; udder, causing mastitis; and eyes, causing ocular conjunctivitis or pinkeye). E. coli is not strictly limited to warmblooded hosts: the species has been observed in the feces of reptiles 
(Souza and others, 1999) and the water cups of bromeliads (Rivera and others, 1988), and it is suspected to sustain viable populations in warm, nutrient-rich environments such as beach sand (Whitman and Nevers, 2003) and beach wrack (Whitman and others, 2003). These observations about host specificity extend also to the total coliforms and fecal coliforms, of which E. coli is a member. Similarly, enterococci have been cultivated from a variety of warmblooded animals (Wheeler and others, 2002), cold-blooded animals (Ott, 2001), and plant surfaces (Kanoe and Abe, 1988). Though perhaps rare, these exceptions to the assumption that fecal-indicator microbes are exclusively associated with the feces of warmblooded animals illustrate that absolute specificity of fecal-indicator bacteria subtypes to species is unlikely.

Souza and others (2002) proposed that hosts act as selective sieves in which only the best adapted subtypes will succeed. The concept of selection does not, however, imply exclusiv-

ity. Regulatory fecal-indicator bacteria have been reported to survive and reproduce in a variety of environments, and none of the regulatory fecal-indicator microorganisms fully exhibits host specificity (table 2). Host specificity for regulated fecal-indicator microorganisms might be best described as "differential distribution." Accuracy of MST is limited, in part, by the extent to which host specificity is absolute. For example, detection of a subtype of $E$. coli that is most often found in cattle might be considered circumstantial evidence that cattle are a source of E. coli to that water. Human-specific adenoviruses and enteroviruses, in contrast, have been observed only in human hosts (Noble and others, 2003). Detection of these human-specific viruses provides strong evidence that humans were a source of fecal contamination to the water sample, but no evidence of how dominant the human source was to overall contamination. None of the alternative indicators of fecal contamination is nearly as well characterized as $E$. coli or enterococci (see Appendix A, sec. A.2), so there is the risk that limitations of alternative indicators will arise as they are studied more closely.

\subsection{Even Distribution Within Host Population}

Few comprehensive studies have been done to evaluate the distribution of source identifiers in their hosts. Perhaps not surprisingly, many of the studies that have been done have emphasized regulatory fecal-indicator microorganisms and pathogens of human health or economic importance. One such organism is E. coli. Gordon and Cowling (2003) measured the distribution of enteric coliform bacteria (of which E. coli is one species) among Australian mammals and found them to be only sporadically detected in component of gut populations (detection threshold $>1$ percent of bacteria capable of growth on MacConkey agar). In other studies, fecal coliform concentrations (of which E. coli is a major component) have been found to vary by orders of magnitude in feces coming from the same species (Geldreich, 1976). Use of $E$. coli concentrations to make interpretations about actual feces loads to the study area might lead to false conclusions. Where information is available, indications are that the other proposed source identifiers also tend to violate the assumption of presence at consistent concentrations in feces of their hosts (table 2). 


\subsection{Stability of Source Identifiers}

\subsubsection{Temporal Stability}

Microorganisms are susceptible to genetic shuffling (genome plasticity). Genome plasticity occurs over timeframes relevant to this discussion because some microorganisms go through many generations in a matter of days (Savageau, 1983). Because bacterial reproduction is asexual, mechanisms for genetic rearrangement are generally within a single generation rather than during the reproductive process. Mechanisms include transfer of genetic material within and between species (conjugation), uptake and incorporation of naked DNA in the environment (transformation), incorporation of virus DNA (lysogeny), and transfer of mobile genetic elements (plasmids; Smith-Keary, 1989). Genome plasticity may affect subtypes defined by genetic fingerprints (pulsed-field gel electrophoresis (PFGE), ribotypes, rep-PCR and others) and phenotypic characteristics partially defined by plasmid-based traits (ARA) more than those defined by a single locus or other target sequence (length heterogeneity PCR, toxin genes, coliphage genotyping). Virus reproduction, through host-mediated replication, is subject to the same random genetic shuffling mechanisms as the host during replication. As with bacteria, some viruses are known to be more prone to genetic recombination and mutation than others. The mechanisms of genome plasticity have been defined and observed; however, actual rates of transformation and recombination in the environment are not well defined in most cases.

In addition to genome plasticity, there are constant shifts in dominance among the enteric microorganisms. Caugant and others (1981) reported finding few "resident" E. coli types and many "transient" types in a human individual over about a year of repeated sampling. Overall, though, 62 percent of $E$. coli isolated from this individual were of the two resident types; thus, at any given time it would seem that a host is most likely to shed the resident type(s). Functional genetic markers may prove to be more temporally stable source indicators. Examples of functional genes include those encoding housekeeping genes (Maynard Smith and others, 2000) and adhesion proteins (Scott and others, 2005). Function-based markers have the dual benefit of conferring host specificity on the carrier organism and limiting fitness of alternates, thereby reducing the chance that individuals not carrying the marker will be shed persistently by the host.

\subsubsection{Spatial Stability}

There may be a geographic area to which each source identifier is limited. Studies of $E$. coli (Hartel and others, 2002; Scott and others, 2003) and enterococci (Wiggins and others, 2003) from known-sources indicate that libraries may be useful across watersheds within a region but not necessarily between regions. The dynamics of population distribution include not only suitability of habitat (host specificity, influenced by local diet and environment) but also transfer and colonization among geographically isolated host populations. An isolated population of host animals may contain a dominant marker, bacteria subtype, or other source identifier that, though suitable for colonization of other host populations, does not get the chance to do so because of geographic separation.

\subsection{Consistent Decay Rates in the Environment}

The failure of the fecal coliform/fecal streptococcus (FC/FS) ratio for use in source tracking was a lesson to heed in current pursuit of MST. This lesson is particularly relevant when attempting to quantify source contributions, which is the objective of many TMDL evaluations, and for less ambitious attempts to designate detected hosts as "major" or "minor" contributors. In the case of the FC/FS ratio, it was initially established that the distribution in fresh human feces is weighted toward fecal coliforms; thus, concentration ratios lower than 0.8 indicated predominantly nonhuman sources, whereas ratios greater than 4 indicated human sources of fecal contamination (Geldreich, 1976). Unfortunately, the relevance of the interpretations was found to be limited to recent contamination events because fecal coliform concentrations decay faster 
than fecal streptococci concentrations; over the course of time, the FC/FS ratio shifts to high numbers (indicative of human sources) regardless of the source of fecal contamination (Clesceri and others, 1998).

Instability of source-indicating ratios (such as FC/FS), or shifts in the relative concentrations of source indicators, can occur through differential die-off rates or processes that change a source identifier's type (such as mutation, exchange of genetic material, or changes in gene expression because of environmental conditions). Selective pressures in the secondary (non-enteric) habitat may very well undermine interpretations based on observations of source identifier characteristics in the primary (enteric) habitat (Savageau, 1983; Gordon and others, 2002). This is a very important potential limitation to development of known-source isolate libraries by use of fresh feces as reference material and use of other microbial ratios to indicate fecal sources.

\subsection{Relevance to Study Objectives}

Study objectives may require direct correlation with regulated fecal-indicator bacteria, direct correlation with human or other health risk, or both. Research that indicates whether each source identifier meets these criteria is described in table 2 . 


\section{References Cited}

Aarestrup, F.M., Agerso, Y., Gerner-Smidt, P., Madsen, M., and Jensen, L.B., 2000, Comparison of antimicrobial resistance phenotypes and resistance genes in Enterococcus faecalis and Enterococcus faecium from humans in the community, broilers, and pigs in Denmark: Diagnostic Microbiology and Infectious Disease, v. 37, p. 127-137.

Albert, J.M., Munakata-Marr, J., Tenorio, L., and Siegrist, R.L., 2003, Statistical evaluation of bacterial source tracking data obtained by rep-PCR DNA fingerprinting of Escherichia coli: Environmental Science \& Technology, v. 37, p. 4554-4560.

Atlas, R.M., 1988, Microbiology (2d ed.): New York, Macmillan Publishing Company, 807 p.

Atlas, R.M., and Bartha, R., 1993, Microbial ecology-Fundamentals and applications: New York, Benjamin/Cummings Publishing Company, 563 p.

Atwill, E.R., Johnson, E., Klingborg, D.J., Veserat, G.M., Markegard, G., Jensen, W.A., Pratt, D.W., Delmas, R.E., George, H.A., Forero, L.C., Philips, R.L., Barry, S.J., McDougald, N.K., Gildersleeve, R.R., and Frost, W.E., 1999, Age, geographic, and temporal distribution of fecal shedding of Cryptosporidium parvum oocysts in cow-calf herds: American Journal of Veterinary Research, v. 60, no. 4, p. 420-425.

Becker, M.F., Peter, K.D., and Masoner, J., 2003, Possible sources of nitrate in ground water at swine licensed-managed feeding operations in Oklahoma, 2001: U.S. Geological Survey Water-Resources Investigations Report 02-4257, $76 \mathrm{p}$.

Beekwilder, J., Nieuwenhuizen, A.H., Havelaar, A.H., and van Duin, J., 1996, An oligonucleotide hybridization assay for the identification and enumeration of F-specific RNA phages in surface water: Journal of Applied Bacteriology, v. 80, p. 179-186.

Bernhard, A.E., and Field, K.G., 2000a, Identification of nonpoint sources of fecal pollution in coastal waters by using host-specific $16 \mathrm{~S}$ ribosomal DNA genetic markers from fecal anaerobes: Applied and Environmental Microbiology, v. 66 , no. 4 , p. $1587-1594$.

Bernhard, A.E., and Field, K.G., 2000b, A PCR assay to discriminate human and ruminant feces on the basis of host differences in Bacteroides-Prevotella genes encoding 16S rRNA: Applied and Environmental Microbiology, v. 66, no. 10 , p. $4571-4574$.
Bernhard, A.E., Goyard, T., Simonich, M.T., and Field, K.G., 2003, Application of a rapid method for identifying fecal pollution sources in a multi-use estuary: Water Research, v. 37, no. 4, p. 909-913.

Bettelheim, K., and Thomas, G., 2004, E. coli serotypes: University of Birmingham, England, accessed January 26, 2005, at http://ecoli.bham.ac.uk/path/sero.html.

Blackwood, A.D., Gregory, J.B., and Noble, R.T., 2003, Determination of the quantitative relationship between indicator bacteria and viral pathogens in recreational waters using quantitative PCR [abs.]: Washington, D.C., Abstracts of the General Meeting of the American Society for Microbiology, v. 103, Q-427.

Boehm and others, 2003, Tiered approach for identification of a human fecal pollution source at a recreational beachCase study at Avalon Bay, Catalina Island, California: Environmental Science \& Technology, v. 37, p. 673-680.

Bonjoch, X., Balleste, E., and Blanch, A.R., 2004, Multiplex PCR with 16S rRNA gene-targeted primers of Bifidobacterium spp. to identify sources of fecal pollution: Applied and Environmental Microbiology, v. 70, no. 5, p. 3171-3175.

Borchardt, M.A., Bertz, P.D., Spencer, S.K., and Battigelli, D.A., 2003, Incidence of enteric viruses in groundwater from household wells in Wisconsin: Applied and Environmental Microbiology, v. 69, p. 1172-1180.

Borrego, J.J., Morinigo, M.A., Vicente, A., Cornx, R., and Romero, P., 1987, Coliphages as an indicator of fecal pollution in water-Its relationship with indicator and pathogenic microorganisms: Water Research, v. 21, p. 1473-1480.

Brenner, K.P., Rankin, C.C., Roybal, Y.R., Stelma, G.N., Scarpino, P.V., and Dufour, A.P., 1993, New medium for the simultaneous detection of total coliforms and Escherichia coli in water: Applied and Environmental Microbiology, v. 59 , no. 11 , p. 3534.

Cabelli, V., Dufour, A.P., McCabe, L.J., and Levin, M.A., 1982, Swimming-associated gastroenteritis and water quality: American Journal of Epidemiology, v. 115, p. 606-616.

Calci, K.R., Burkhardt, W., III, Watkins, W.D., and Rippey, S.R., 1998, Occurrence of male-specific bacteriophage in feral and domestic animal wastes, human feces, and human-associated wastewaters: Applied and Environmental Microbiology, v. 64, no. 12, p. 5027-5029.

Carrillo, M., Estrada, E., and Hazen, T.C., 1985, Survival and enumeration of the fecal indicators Bifidobacterium adolescentis and Escherichia coli in a tropical rain forest watershed: Applied and Environmental Microbiology, v. 50, p. $468-476$. 
Carson, C.A., Shear, B.L., Ellersieck, M.R., and Asfaw, A., 2001, Identification of fecal Escherichia coli from humans and animals by ribotyping: Applied and Environmental Microbiology, v. 67, no. 4, p. 1503-1507.

Carson, C.A., Shear, B.L., Ellersieck, M.R., and Schnell, J.D., 2003, Comparison of ribotyping and repetitive extragenic palindromic-PCR for identification of fecal Escherichia coli from humans and animals: Applied and Environmental Microbiology, v. 69, no. 3, p. 1836-1839.

Caugant, D.A., Levin, B.R., and Selander, R.K., 1981, Genetic diversity and temporal variation in the $E$. coli population of a human host: Genetics, v. 98, p. 467-490.

Caugant, D.A., Levin, B.R., and Selander, R.K., 1984, Distribution of multilocus genotypes of Escherichia coli within and between host families: Journal of Hygiene, v. 92, p. 377-384.

Centers for Disease Control and Prevention, 1996, Standardized molecular subtyping of foodborne bacterial pathogens by pulsed-field gel electrophoresis (updated 2000 ed.): Atlanta, Ga., National Center for Infectious Diseases, Centers for Disease Control and Prevention.

Chalmers, R.M., Sturdee, A.P., Bull, S.A., Miller, A., and Wright, S.E., 1997, The prevalence of Cryptosporidium parvum and C. muris in Mus domesticus, Apodemus sylvaticus and Clethrionomys glareolus in an agricultural system: Parasitology Research, v. 83, no. 5, p. 478-482.

Chern, E.C., Tsai, Y., and Olson, B.H., 2004, Occurrence of genes associated with enterotoxigenic and enterohemorrhagic Escherichia coli in agricultural waste lagoons: Applied and Environmental Microbiology, v. 70, no. 1, p. 356-362.

Clesceri, L.S., Greenberg, A.E., and Eaton, A.D., eds., 1998, Standard methods for the examination of water and waste water: Washington, D.C., American Public Health Association [variously paginated].

Cole, D., Long, S.C., and Sobsey, M.D., 2003, Evaluation of F+RNA and DNA coliphages as source-specific indicators of fecal contamination in surface waters: Applied and Environmental Microbiology, v. 69, no. 11, p. 6507-6514.

Cooke, E.M., Ewins, S., and Shooter, R.A., 1969, Changing faecal population of Escherichia coli in hospital medical patients: British Medical Journal, v. 4, p. 593-595.

Delahoya, N.C., Kramer, M.F., Whitlock, J.E., Harwood, V.J., and Lim, D.V., 2002, Survey of Enterococcus species from various sources using API 20 strip and PCR methods for species identification [abs]: Abstracts of the General Meeting of the American Society for Microbiology, v. 102, p. 389 .
Dick, L.K., and Field, K.G., 2004, Rapid estimation of numbers of fecal Bacteroidetes by use of a quantitative PCR assay for 16S rRNA genes: Applied and Environmental Microbiology, v. 70, no. 9, p. 5695-5697.

Dick, L.K., Field, K.G., Brodeur, T., Simonich, M., and Pester, M., 2002, Phylogenetic analysis of fecal Bacteroides-Prevotella and development of host-specific PCR primers for source identification of fecal contamination [abs.]: Abstracts of the General Meeting of the American Society for Microbiology, v. 102.

Dombek, P.E., Johnson, L.K., Zimmerley, S.T., and Sadowsky, M.J., 2000, Use of repetitive DNA sequences and the PCR to differentiate Escherichia coli isolates from human and animal sources: Applied and Environmental Microbiology, v. 66 , no. 6 , p. 2572-2577.

Dufour, A.P., 1984, Health effects criteria for fresh recreational waters: Research Triangle Park, N.C., U.S. Environmental Protection Agency, Office of Research and Development, EPA-600/1-84-004, 33 p.

Dumouchelle, D.D., and Stoeckel, D.M., 2005, Preliminary investigations of wastewater-related contaminants near home sewage treatment systems in Ohio: U.S. Geological Survey Open File Report 2005-1282, 31 p.

Duncan, C.S., Reneau, R.R.J., and Hagedorn, C., 1994, Impact of effluent quality and soil depth on renovation of domestic wastewater: Proceedings of the Seventh International Symposium on Individual and Small Community Sewage Systems, p. 219-228.

Farnleitner, A.H., Kreuzinger, N., Kavka, G.G., Grillenberger, S., Rath, J., and Mach, R.L., 2000, Simultaneous detection and differentiation of Escherichia coli populations from environmental freshwaters by means of sequence variations in a fragment of the beta-D glucuronidase gene: Applied and Environmental Microbiology, v. 66, no. 4, p. $1340-1346$.

Fayer, R., Morgan, U., and Upton, S.J., 2000, Epidemiology of Cryptosporidium - Transmission, detection and identification: International Journal for Parasitology, v. 30, no. 12-13, p. 1305-1322.

Field, K.G., Chern, E.C., Dick, L.K., Fuhrman, J., Griffith, J., Holden, P.A., LaMontagne, M.G., Le, J., Olson, B., and Simonich, M.T., 2003, A comparative study of culture-independent, library-independent genotypic methods of fecal source tracking. Journal of Water and Health, v. 1, no. 4, p. 181-194.

Franke, S., Harmsen, D., Caprioli, A., Pierard, D., Wieler, L.H., and Karch, H., 1995, Clonal relatedness of shiga-like toxin producing Escherichia coli O101 strains of human and porcine origin: Journal of Clinical Microbiology, v. 33, p. 3174-3178. 
Franks, A.H., Harmsen, H.J.M., Raangs, G.C., Jansen, G.J., Schut, F., and Welling, G.W., 1998, Variations of bacterial populations in human feces measured by fluorescent in situ hybridization with group-specific $16 \mathrm{~S}$ rRNA-targeted oligonucleotide probes: Applied and Environmental Microbiology, v. 64, no. 9, p. 3336-3345.

Furuse, K., 1987, Distribution of coliphages in the environment—general considerations, in Goyal, S.M., Gerba, C.P. and Bitton, G., eds., Phage ecology: New York, John Wiley \& Sons, p. 87-124.

Geldreich, E.E., 1976, Faecal coliform and faecal streptococcus density relationships in waste discharges and receiving waters: Critical Reviews in Environmental Control, v. 6, p. 349-369.

Geldreich, E.E., and Kenner, B.A., 1969, Concepts of fecal streptococci in stream pollution: Journal of the Water Pollution Control Federation, v. 41, no. 8, Supplement p. R336-352.

Gerba, C.P., Gramos, D.M., and Nwachuku, N., 2002, Comparative inactivation of enteroviruses and adenovirus 2 by UV light: Applied and Environmental Microbiology, v. 68, no. 10 , p. 5167-5169.

Gordon, D.M., 2001, Geographical structure and host specificity in bacteria and the implications for tracing the source of coliform contamination: Microbiology, v. 147, p. 10791085.

Gordon, D.M., Bauer, S., and Johnson, J.R., 2002, The genetic structure of Escherichia coli populations in primary and secondary habitats: Microbiology, v. 148, p. 1513-1522.

Gordon, D.M., and Cowling, A., 2003, The distribution and genetic structure of Escherichia coli in Australian vertebrates-Host and geographic effects: Microbiology, v. 149, p. $3575-3586$.

Graves, A.K., Hagedorn, C., Teetor, A., Mahal, M., Booth, A.M., and Reneau, R.B., Jr., 2002, Antibiotic resistance profiles to determine sources of fecal contamination in a rural Virginia watershed: Journal of Environmental Quality, v. 31 , p. $1300-1308$.

Griffin, D.W., Gibson, C.J., III, Lip, E.K., Riley, K., Paul, J.H., III, and Rose, J.B., 1999, Detection of viral pathogens by reverse transcriptase PCR and of microbial indicators by standard methods in the canals of the Florida Keys: Applied and Environmental Microbiology, v. 65, no. 9, p. $4118-4125$.

Griffin, D.W., Stokes, R., Rose, J.B., and Paul, J.H.,III, 2000, Bacterial indicator occurrence and the use of an F+ specific RNA coliphage assay to identify fecal sources in Homosassa Springs, Florida: Microbial Ecology, v. 39, no. 1, p. 56-64.
Griffith, J.F., Weisberg, S.B., and McGee, C.D., 2003, Evaluation of microbial source tracking methods using mixed fecal sources in aqueous test samples: Journal of Water and Health, v. 1, no. 4, p. 141-151.

Guan, S., Xu, R., Chen, S., Odumeru, J., and Gyles, C., 2002, Development of a procedure for discriminating among Escherichia coli isolates from animal and human sources: Applied and Environmental Microbiology, v. 68, no. 6, p. 2690-2698.

Hagedorn, C., 1999, Developing methods for bacterial source tracking , in [Proceedings] 10th Annual meeting, Northwest On-Site Wastewater Treatment Short Course and Equipment Exhibition: Seattle, Wash., 64 p.

Hagedorn, C., Crozier, J.B., Mentz, K.A., Booth, A.M., Graves, A.K., Nelson, N.J., and Reneau, R.B., Jr., 2003, Carbon source utilization profiles as a method to identify sources of faecal pollution in water: Journal of Applied Microbiology, v. 94, no. 5, p. 792-799.

Hagedorn, C., Robinson, S.L., Filz, J.R., Grubbs, S.M., Angier, T.A., and Reneau, R.B., Jr., 1999, Determining sources of fecal pollution in a rural Virginia watershed with antibiotic resistance patterns in fecal streptococci: Applied and Environmental Microbiology, v. 65, no. 12, p. 5522-5531.

Hancock, T.C., Miller, C.V., Denver, J.M., and Riedel, G.F., 2000, Fate and transport of arsenical feed amendments in Chesapeake Bay watersheds [abst.]: Society of Environmental Toxicology and Chemistry Annual Meeting, 21st, Nashville, November 12-16, 2000.

Hartel, P.G., Frick, E.A., Funk, A.L., Hill, J.L., Summer, J.D., and Gregory, M.B., 2004, Sharing of ribotype patterns of Escherichia coli isolates during baseflow and stormflow conditions: U.S. Geological Survey Scientific Investigations Report 2004-5004, 10 p.

Hartel, P.G., Summer, J.D., Hill, J.L., Collins, V.J., Entry, J.A., and Segars, W.I., 2002, Geographic variability of Escherichia coli ribotypes from animals in Idaho and Georgia: Journal of Environmental Quality, v. 31, p. 1273-1278.

Harwood, V.J., Whitlock, J., and Withington, V., 2000, Classification of antibiotic resistance patterns of indicator bacteria by discriminant analysis-Use in predicting the source of fecal contamination in subtropical waters: Applied and Environmental Microbiology, v. 66, no. 9, p. 3698-3704.

Harwood, V.J., Wiggins, B., Hagedorn, C., Ellender, R.D., Gooch, J., Kern, J., Samadpour, M., Chapman, A.C.H., Robinson, B.J., and Thompson, B.C., 2003, Phenotypic library-based microbial source tracking methods-Efficacy in the California collaborative study: Journal of Water and Health, v. 1, no. 4, p. 153-166. 
Havelaar, A.H., 1993, Bacteriophages as models of human enteric viruses in the environment: American Society for Microbiology News, v. 59, no. 614, p. 619.

Heitman, T.L., Frederick, L.M., Viste, J.R., Guselle, N.J., Morgan, U.M., Thompson, R.C.A., and Olson, M.E., 2002, Prevalence of Giardia and Cryptosporidium and characterization of Cryptosporidium spp. isolated from wildlife, human, and agricultural sources in the North Saskatchewan River Basin in Alberta, Canada: Canadian Journal of Microbiology, v. 48, no. 6, p. 530-541.

Hsu, F., Shieh, Y.C., van Duin, J., Beekwilder, M.J., and Sobsey, M.D., 1995, Genotyping male-specific RNA coliphages by hybridization with oligonucleotide probes: Applied and Environmental Microbiology, v. 61, p. 3960-3966.

Hutchison, M.L., Walters, L.D., Avery, S.M., Synge, B.A., and Moore, A., 2004, Levels of zoonotic agents in British livestock manures: Letters in Applied Microbiology, v. 39, no. 2, p. 207-214.

Hyer, K.E., and Moyer, D.L., 2003, Patterns and sources of fecal coliform bacteria in three streams in Virginia, 19992000: U.S. Geological Survey Water Resources Investigations Report 03-4115, 76 p.

Hyer, K.E., and Moyer, D.L., 2004, Enhancing fecal coliform total maximum daily load models through bacterial source tracking: Journal of the American Water Resources Association, v. 40, no. 6, p. 1511-1526.

Jenkins, M.B., Hartel, P.G., Olexa, T.J., and Stuedemann, J.A., 2003, Putative temporal variability of Escherichia coli ribotypes from yearling steers: Journal of Environmental Quality, v. 32, p. 305-309.

Jiang, S., Noble, R., and Chu, W., 2001, Human adenoviruses and coliphages in urban runoff-impacted coastal waters of Southern California: Applied and Environmental Microbiology, v. 67, p. 179-184.

Jiménez-Clavero, M.A., Fernández, C., Ortiz, J.A., Pro, J., Carbonell, G., Tarazona, J.V., Roblas, N., and Ley, V., 2003, Teschoviruses as indicators of porcine fecal contamination of surface water: Applied and Environmental Microbiology, v. 69 , no. 10, p. $6311-6315$.

Jofre, J., Ollé, E., Ribs, F., Vidal, A., and Lucena, F., 1995, Potential usefulness of bacteriophages that infect Bacteroides fragilis as model organisms for monitoring virus removal in drinking water treatment plants: Applied and Environmental Microbiology, v. 61, no. 9, p. 3227-3231.

Kanoe, M., and Abe, T., 1988, Enterococcal isolates from environmental sources: Microbios Letters, v. 38, p. 15-20.
Khatib, L.A., Tsai, Y.L., and Olson, B.H., 2002, A biomarker for the identification of cattle fecal pollution in water using the LTIIa toxin gene from enterotoxigenic Escherichia coli: Applied Microbiology and Biotechnology, v. 59, no. 1, p. 97-104.

Khatib, L.A., Tsai, Y.L., and Olson, B.H., 2003, A biomarker for the identification of swine fecal pollution in water, using the STII toxin gene from enterotoxigenic Escherichia coli: Applied Microbiology and Biotechnology, v. 63, no. 2, p. 231-238.

Kopecka, H., Dubrou, S., Prevot, J., Marechal, J., and LopezPila, J.M., 1993, Detection of naturally occurring enteroviruses in waters by reverse transcription, polymerase chain reaction, and hybridization: Applied and Environmental Microbiology, v. 59, no. 4, p. 1213-1219.

Kreader, C.A., 1998, Persistence of PCR-detectable Bacteroides distasonis from human feces in river water: Applied and Environmental Microbiology, v. 64, no. 10, p. 4103-4105.

Kuntz, R.L., Hartel, P.G., Godfrey, D.G., McDonald, J.L., Gates, K.W., and Segars, W.I., 2003, Targeted sampling protocol as prelude to bacterial source tracking with Enterococcus faecalis: Journal of Environmental Quality, v. 32, no. 6, p. 2311-2318.

Leclerc, H., Mossel, D.A., Edberg, S.C., and Struijk, C.B., 2001, Advances in the bacteriology of the coliform groupTheir suitability as markers of microbial water safety: Annual Reviews in Microbiology, v. 55, p. 201-234.

Ley, V., Higgins, J., and Fayer, R., 2002, Bovine enteroviruses as indicators of fecal contamination: Applied and Environmental Microbiology, v. 68, no. 7, p. 3455-3461.

Long, S.C., and Plummer, J.D., 2004, Assessing land use impacts on water quality using microbial source tracking: Journal of the American Water Resources Association, v. 40 , no. 6 , p. $1433-1448$.

Louws, F.J., Rademaker, J.L.W., and de Bruijn, F.J., 1999, The three Ds of PCR-based genomic analysis of phytobacteriaDiversity, detection, and disease diagnosis: Annual Review of Phytopathology, v. 37, p. 81-125.

Mallon, M., MacLeod, A., Wastling, J., Smith, H., Reilly, B., and Tait, A., 2003, Population structures and the role of genetic exchange in the zoonotic pathogen Cryptosporidium parvum: Journal of Molecular Evolution, v. 56, no. 4, p. 407-417.

Maluquer de Motes, Carlos; Clemente-Cesares, P.; Hundesa, A.; Martín, M.; and Girones, R., 2004, Detection of bovine and porcine adenoviruses for tracing the source of fecal contamination: Applied and Environmental Microbiology, v. 70 , no. 3, p. 1448-1454. 
Mancl, Karen, and Slater, Brian, 2002, Suitability of Ohio soils for treating wastewater: Columbus, Ohio, The Ohio State University, Extension Bulletin 896, accessed 27 July 2005 at $h t t p: / / o h i o l i n e . o s u . e d u / b 896$.

Mara, D.D., and Oragui, J.I., 1983, Sorbitol-fermenting bifidobacteria as specific indicators of human faecal pollution: Journal of Applied Bacteriology, v. 55, p. 349-357.

Marteau, P., Pochart, P., Doré, J., Béra-Maillet, C., Bernalier, A., and Corthier, G., 2001, Comparative study of bacterial groups within the human cecal and fecal microbiota: Applied and Environmental Microbiology, v. 67, no. 10, p. 4939-4942.

Maynard Smith, J., Feil, E.J., and Smith, N.H., 2000, Population structure and evolutionary dynamics of pathogenic bacteria: BioEssays, v. 22, p. 1115-1122.

McLellan, S.L., Daniels, A.D., and Salmore, A.K., 2003, Genetic characterization of Escherichia coli populations from host sources of fecal pollution by using DNA fingerprinting: Applied and Environmental Microbiology, v. 69, no. 5, p. 2587-2594.

Miescier, J.J., and Cabelli, V.J., 1982, Enterococci and other microbial indicators in municipal wastewater effluents: Journal of the Water Pollution Control Federation, v. 54, p. 1599-1606.

Monpoeho, S., Dehee, A., Mignotte, B., Schwartzbrod, L., Marechal, V., Nicolas, J.-C., Billaudel, S., and Ferre, B., 2000, Quantification of enterovirus RNA in sludge samples using single tube real-time RT-PCR: BioTechniques, v. 29, no. 1, p. $88-93$.

Myoda, S.P., Carson, C.A., Fuhrmann, J.J., Hahm, B.K., Hartel, P.G., Yampara Iquise, H., Johnson, L.A., Kuntz, R.L., Nakatsu, C.H., Sadowsky, M.J., and Samadpour, M., 2003, Comparison of genotypic-based microbial source tracking methods requiring a host origin database: Journal of Water and Health, v. 1, no. 4, p. 167-180.

Noble, R.T., Allen, S.M., Blackwood, A.D., Chu, W., Jiang, S.C., Lovelace, G.L., Sobsey, M.D., Stewart, J.R., and Wait, D.A., 2003, Use of viral pathogens and indicators to differentiate between human and non-human fecal contamination in a microbial source tracking comparison study: Journal of Water and Health, v. 1, no. 4, p. 195-207.

Noble, R.T., and Fuhrman, J.A., 2001, Enteroviruses detected by reverse transcriptase polymerase chain reaction from the coastal waters of Santa Monica Bay, California-Low correlation to bacterial indicator levels: Hydrobiologia, v. 460, p. $175-184$.

Olive, D.M., and Bean, P., 1999, Principles and applications of methods for DNA-based typing of microbial organisms: Journal of Clinical Microbiology, v. 37, p. 1661-1669.
Olson, M.E., Goh, J., Phillips, M., Guselle, N., and McAllister, T.A., 1999, Giardia cyst and Cryptosporidium oocyst survival in water, soil, and cattle feces: Journal of Environmental Quality, v. 28, no. 6, p. 1991-1996.

Ong, C.S.L., Eisler, D.L., Alikhani, A., Fung, V.W.K., Tomblin, J., Bowie, W.R., and Isaac-Renton, J.L., 2002, Novel Cryptosporidium genotypes in sporadic cryptosporidiosis cases-First report of human infections with a cervine genotype: Emerging Infectious Diseases, v. 8, p. 263-268.

Oppegaard, H., Steinum, T.M., and Wasteson, Y., 2001, Horizontal transfer of a multi-drug resistance plasmid between coliform bacteria of human and bovine origin in a farm environment: Applied and Environmental Microbiology, v. 67 , no. 8 , p. 3732-3734.

Oshiro, R.K., and Olson, B.H., 1995, Occurrence of the STh toxin gene in animal feces, primary unchlorinated sewage and environmental water samples using PCR and hybridization techniques [abs.]: Abstracts of the General Meeting of the American Society for Microbiology, v. 95, p. 435.

Ott, E., Muller, T., Franz, C.M.A.P., Ulrich, A., Gabel, M., and Seyfarth, W., 2001, Population dynamics and antagonistic potential of enterococci colonizing the phyllosphere of grasses: Journal of Applied Microbiology, v. 91, p. 54-66.

Parveen, S., Hodge, N.C., Stall, R.E., Farrah, S.R., and Tamplin, M.L., 2001, Phenotypic and genotypic characterization of human and nonhuman Escherichia coli: Water Research, v. 35 , p. 379-386.

Parveen, S., Murphree, R.L., Edmiston, L.E.E., Kaspar, C.W., Portier, K.M., and Tamplin, M.L., 1997, Association of multiple-antibiotic-resistance profiles with point and nonpoint sources of Escherichia coli in Apalachicola Bay: Applied and Environmental Microbiology, v. 63, no. 7, p. 2607-2612.

Parveen, S., Portier, K.M., Robinson, K., Edmiston, L., and Tamplin, M., 1999, Discriminant analysis of ribotype profiles of Escherichia coli for differentiating human and nonhuman sources of fecal pollution: Applied and Environmental Microbiology, v. 65, no. 7, p. 3142-3147.

Persing, D.H., Smith, T.F., Tenover, F.C., and White, T.J., 1993, Diagnostic molecular microbiology_Principles and applications: Washington, D.C., American Society for Microbiology, $641 \mathrm{p}$.

Pickett, C.L., Weinstein, D.L., and Holmes, R.K., 1987, Genetics of type IIa heat-labile enterotoxin of Escherichia coli-Operon fusions, nucleotide sequence, and hybridization studies: Journal of Bacteriology, v. 168, p. 5180-5187. 
Piña, S., Puig, M., Lucena, F., Jofre, J., and Girones, R., 1998, Viral pollution in the environment and in shellfish-Human adenovirus detection by PCR as an index of human viruses: Applied and Environmental Microbiology, v. 64, no. 9, p. 3376-3382.

Pourcher, A.M., Devriese, L.A., Hernandez, J.F., and Delattre, J.M., 1991, Enumeration by a miniaturized method of Escherichia coli, Streptococcus bovis, and enterococci as indicators of the origin of fecal pollution of waters: Journal of Applied Bacteriology, v. 70, no. 6, p. 525-530.

Puig, A., Queralt, N., Jofre, J., and Araujo, R., 1999, Diversity of Bacteroides fragilis strains in their capacity to recover phages from human and animal wastes and from fecally polluted wastewater: Applied and Environmental Microbiology, v. 65, no. 4, p. 1772-1776.

Rademaker, J., and de Bruijn, F.J., 1997, Characterization and classification of microbes by REP-PCR genomic fingerprinting and computer assisted pattern analysis, in CaetanoAnolles, G., and Gresshoff, P.M. eds. DNA markers-Protocols, applications, and overviews: New York, Wiley-Liss, p. 151-172.

Ram, J.L., Ritchie, R.P., Fang, J., Gonzales, F., and Selegean, J.P., 2004, Sequence-based source tracking of Escherichia coli based on genetic diversity of beta-glucuronidase: Journal of Environmental Quality, v. 33, p. 1024-1032.

Refsum, T., Heir, E., Kapperud, G., Vardund, T., and Holstad, G., 2002, Molecular epidemiology of Salmonella enterica serovar typhimurium isolates determined by pulsed-field gel electrophoresis-Comparison of isolates from avian wildlife, domestic animals, and the environment in Norway: Applied and Environmental Microbiology, v. 68, p. 5600-5606.

Reynolds, K.A., Roll, K., Fujioka, R.S., Gerba, C.P., and Pepper, I.L., 1998, Incidence of enteroviruses in Mamala Bay, Hawaii using cell culture and direct polymerase chain reaction methodologies: Canadian Journal of Microbiology, v. 44 , no. 6 , p. 598-604.

Rhodes, M.W., and Kator, H., 1997, Enumeration of Enterococcus sp. using a modified mE method: Journal of Applied Microbiology, v. 83, no. 1, p. 120-126.

Ritter, K.J., Carruthers, E., Carson, C.A., Ellender, R.D., Harwood, V.J., Kingsley, K., Nakatsu, C., Sadowsky, M., Shear, B., West, B., Whitlock, J.E., Wiggins, B.A., and Wilbur, J.D., 2003, Assessment of statistical methods used in library-based approaches to microbial source tracking: Journal of Water and Health, v. 1, no. 4, p. 209-223.

Rivera, S.C., Hazen, T.C., and Toranzos, G.A., 1988, Isolation of fecal coliforms from pristine sites in a tropical rain forest: Applied and Environmental Microbiology, v. 54, no. 2, p. 513-517.
Samadpour, M., and Chechowitz, N., 1995, Little Soos Creek microbial source tracking-A survey: Seattle, Wash., University of Washington, Department of Environmental Health, 49 p.

Satokari, R.M., Vaughan, E.E., Akkermans, A.L., Saarela, M., and de Vos, W.M., 2001, Bifidobacterial diversity in human feces detected by genus-specific PCR and denaturing gradient gel electrophoresis: Applied and Environmental Microbiology, v. 67, no. 2, p. 504-513.

Savageau, M.A., 1983, Escherichia coli habitats, cell types, and molecular mechanisms of gene control: American Naturalist, v. 122, p. 732-744.

Savelkoul, P.H.M., Aarts, H.J.M., de Haas, J., Dijkshoorn, L., Duim, B., Otsen, M., Rademaker, J.L.W., Schouls, L., and Lenstra, J.A., 1999, Amplified-fragment length polymorphism analysis - The state of an art: Journal of Clinical Microbiology, v. 37, no. 10, p. 3083-3091.

Schaper, M., Duran, A.E., and Jofre, J., 2002, Comparative resistance of phage isolates of four genotypes of F-specific RNA bacteriophages to various inactivation processes: Applied and Environmental Microbiology, v. 68, no. 8, p. 3702-3707.

Schaper, M., Jofre, J., Uys, M., and Grabow, W.O.K., 2002, Distribution of genotypes of F-specific RNA bacteriophages in human and non-human sources of faecal pollution in South Africa and Spain: Journal of Applied Microbiology, v. 92 , p. 657-667.

Scott, T.M., Jenkins, T.M., Lukasik, J., and Rose, J.B., 2005, Potential use of a host associated molecular marker in Enterococcus faecium as an index of human fecal pollution: Environmental Science \& Technology, v. 39, no. 1, p. 283-287.

Scott, T.M., Parveen, S., Portier, K.M., Rose, J.B., Tamplin, M.L., Farrah, S.R., Koo, A., and Lukasik, J., 2003, Geographical variation in ribotype profiles of Escherichia coli isolates from humans, swine, poultry, beef, and dairy cattle in Florida: Applied and Environmental Microbiology, v. 69, no. 2, p. 1089-1092.

Scott, T.M., Rose, J.B., Jenkins, T.M., Farrah, S.R., and Lukasik, J., 2002, Microbial source tracking-Current methodology and future directions: Applied and Environmental Microbiology, v. 68, p. 5796-5803.

Sears, H.J., and Brownlee, I., 1952, Further observations on the persistence of individual strains of Escherichia coli in the intestinal tract of man: Journal of Bacteriology, v. 63, p. 47-57. 
Seurinck, S., Defoirdt, T., Verstraete, W., and Siciliano, S.D., 2005, Detection and quantification of the human-specific HF183 Bacteroides 16S rRNA genetic marker with realtime PCR for assessment of human faecal pollution in freshwater: Environmental Microbiology, v. 7, no. 2, p. 249-259.

Simmons, G.M., Waye, D.F., Herbein, S., Myers, S., and Walker, E., 2000, Estimating nonpoint fecal coliform sources in Northern Virginia's Four Mile Run watershed, in Younos, T., and Poff, J., eds., Abstracts of the Virginia Water Research Symposium 2000: Blacksburg, Va., Virginia Water Resources Research Center Special Report SR-19, p. 248-267.

Simmons, O.D., III, and Sobsey, M.D., 2002, Survival of Cryptosporidium oocysts in environmental water samples [abs.]: Abstracts of the General Meeting of the American Society for Microbiology, v. 102, p. 427.

Simpson, J.M., Santo Domingo, J.W., and Reasoner, D.J., 2002, Microbial source tracking-State of the science: Environmental Science \& Technology, v. 36, p. 5279-5288.

Sinton, L.W., Finlay, R.K., and Hannah, D.J., 1998, Distinguishing human from animal faecal contamination in water-A review: New Zealand Journal of Marine and Freshwater Research, v. 32, p. 323-348.

Sinton, L.W., Finlay, R.K., and Lynch, P.A., 1999, Sunlight inactivation of fecal bacteriophages and bacteria in sewagepolluted seawater: Applied and Environmental Microbiology, v. 65, no. 8, p. 3605-3613.

Smith-Keary, P., 1989, Molecular genetics of Escherichia coli: London, Guilford Press, 198 p.

Souza, V., Rocha, M., Valera, A., and Eguiarte, L.E., 1999, Genetic structure of natural populations of Escherichia coli in wild hosts on different continents: Applied and Environmental Microbiology, v. 65, no. 8, p. 3373-3385.

Souza, V., Travisano, M., Turner, P.E., and Eguiarte, L.E., 2002, Does experimental evolution reflect patterns in natural populations? E. coli strains from long-term studies compared with wild isolates: Antonie van Leeuwenhoek, v. 81, p. 143-153.

Stackebrandt, E., 2003, The richness of prokaryotic diversity-There must be a species somewhere: Food Technology and Biotechnology, v. 41, no. 1, p. 17-22.

Stern, M.J., Ames, G.F., Smith, N.H., Robinson, E.C., and Higgins, C.F., 1984, Repetitive extragenic palindromic sequences-A major component of the bacterial genome: Cell, v. 37, p. 1015-1026.
Stoeckel, D.M., Mathes, M.V., Hyer, K.E., Hagedorn, C., Kator, H., Lukasik, J., O’Brien, T., Fenger, T.W., Samadpour, M., Strickler, K.M., and Wiggins, B.A., 2004, Comparison of seven protocols to identify fecal contamination sources using Escherichia coli: Environmental Science \& Technology, v. 38, no. 22, p. 6109-6117.

Struelens, M.J., 1998, Molecular epidemiologic typing systems of bacterial pathogens-Current issues and perspectives: Memorias del Instituto Oswaldo Cruz, Rio de Janeiro, v. 93, p. 581-585.

Sturdee, A.P., Chalmers, R.M., and Bull, S.A., 1999, Detection of Cryptosporidium oocytes in wild mammals of mainland Britain: Veterinary parasitology, v. 80, no. 4, p. 273-280.

Tannock, G.W., 1995, Normal microflora-An introduction to microbes inhabiting the human body: London, Chapman and Hall, 115 p.

Tartera, C., Lucena, F., and Jofre, J., 1989, Human origin of Bacteroides fragilis bacteriophages present in the environment: Applied and Environmental Microbiology, v. 55, no. 10, p. 2696-2701.

Tenover, F.C., Arbeit, R.D., and Goering, R.V., 1997, How to select and interpret molecular strain typing methods for epidemiological studies of bacterial infections-A review for healthcare epidemiologists: Infection Control and Hospital Epidemiology, v. 18, p. 426-439.

Toivanen, P., Vaahtovuo, J., and Eerola, E., 2001, Influence of major histocompatibility complex on bacterial composition of fecal flora: Infection and Immunity, v. 69, p. 2372-2377.

Turbow, D.J., Osgood, N.D., and Jiang, S.C., 2003, Evaluation of recreational health risk in coastal waters based on enterococcus densities and bathing patterns: Environmental Health Perspectives, v. 111, no. 4, p. 598-603.

U.S. Congress, 2000, Beaches environmental assessment and coastal health (BEACH) act: U.S. Congress, 106th, Public Law 106-284, 114 STAT. 33 USC 1251 p. 870-877 accessed July 27, 2005 at http://www.epa.gov/waterscience/beaches/ bacteria-rule.htm\#final

U.S. Environmental Protection Agency, 1986, Ambient water quality criteria for bacteria-1986: Washington, D.C., Office of Water Regulations and Standards, EPA440/5-84002, 18 p.

U.S. Environmental Protection Agency, 1996, Drinking water regulations and health advisories: Washington, D.C., EPA 822-B-96-002 [24 p].

U.S. Environmental Protection Agency, 2000a, Improved enumeration methods for the recreational water quality indicators-Enterococci and Escherichia coli: Washington, D.C., Office of Science and Technology, $27 \mathrm{p}$. 
U.S. Environmental Protection Agency, 2000b, Atlas of America's polluted waters: Washington, D.C., Office of Water (4503F), EPA 840-B00-002, 53 p.

U.S. Environmental Protection Agency, 2000c, National primary drinking water regulations-Ground Water Rule; proposed rules: Washington, D.C., U.S. Government Printing Office, 40 CFR parts 141 and 142, p. 30194.

U.S. Environmental Protection Agency, 2001, Protocol for developing pathogen TMDLs (1st ed.): Washington, D.C., Office of Water (4503F), EPA 841-R-00-002 [variously paginated].

U.S. Environmental Protection Agency, 2002, National beach guidance and required performance criteria for grants; Appendix G-Conducting a sanitary survey: Washington, D.C., Office of Water (4305 T), EPA-823-B-02-004, p. G1-G7.

U.S. Food and Drug Administration, 2003, National shellfish sanitation program guide for the control of molluscan shellfish: Washington, D.C., U.S. Government Printing Office, accessed July 27, 2005 at http://www.cfsan.fda.gov/ ear/ nss2-toc.html

van Belkum, A., Struelens, M., de Visser, A., Verbrugh, H., and Tibayrenc, M., 2001, Role of genomic typing in taxonomy, evolutionary genetics, and microbial epidemiology: Clinical Microbiology Reviews, v. 14, p. 547-560.

Vaneechoutte, M., and Heyndrickx, M., 2001, Application and analysis of ARDRA patterns in bacterial identification, taxonomy, and phylogeny, in Dijkshoorn, L., Towner, K.J., and Struelens, M., eds. New approaches for the generation and analysis of microbial typing data: Amsterdam, Elsevier Science, p. 211-247.

Vinje, J., Oudejans, S.J.G., Stewart, J.R., Sobsey, M.D., and Long, S.C., 2004, Molecular detection and genotyping of male-specific coliphages by RT-PCR and reverse line blot hybridization: Applied and Environmental Microbiology, v. 70 , no. 10 , p. 5996-6004.

Wheeler, A.L., Hartel, P.G., Godfrey, D.G., Hill, J.L., and Segars, W.I., 2002, Potential of Enterococcus faecalis as a human fecal indicator for microbial source tracking: Journal of Environmental Quality, v. 31, p. 1286-1293.

Whitlock, J.E., Jones, D.T., and Harwood, V.J., 2002, Identification of the sources of fecal coliforms in an urban watershed using antibiotic resistance analysis. Water Research, v. 36 , no. 17 , p. $4273-4282$.

Whitman, R.L., and Nevers, M., 2003, Foreshore sand as a source of Escherichia coli in nearshore water of a Lake Michigan beach: Applied and Environmental Microbiology, v. 69 , no. 9 , p. 5555-5562.
Whitman, R.L., Shiveley, D.A., Pawlik, H., Nevers, M.B., and Byappanahalli, M.N., 2003, Occurrence of Escherichia coli and enterococci in Cladophora (Chlorophyta) in nearshore water and beach sand of Lake Michigan: Applied and Environmental Microbiology, v. 69, no. 8, p. 4714-4719.

Whittam, T.S., 1989, Clonal dynamics of Escherichia coli in its natural habitat: Antonie van Leeuwenhoek, v. 55, p. 23-32.

Wiggins, B.A., 1996, Discriminant analysis of antibiotic resistance patterns in fecal streptococci-A method to differentiate human and animal sources of fecal pollution in natural waters: Applied and Environmental Microbiology, v. 62, no. 11, p. 3997-4002.

Wiggins, B.A., Andrews, R.W., Conway, R.A., Corr, C.L., Dobratz, E.J., Dougherty, D.P., Eppard, J.R., Knupp, S.R., Limjoco, M.C., Mettenburg, J.M., Rinehardt, J.M., Sonsino, J., Torrijos, R.L., and Zimmerman, M.E., 1999, Use of antibiotic resistance analysis to identify nonpoint sources of fecal pollution: Applied and Environmental Microbiology, v. 65 , no. 8 , p. $3483-3486$.

Wiggins, B.A., Cash, P.W., Creamer, W.S., Dart, S.E., Garcia, P.P., Gerecke, T.M., Han, J., Henry, B.L., Hoover, K.B., Johnson, E.L., Jones, K.C., McCarthy, J.G., McDonough, J.A., Mercer, S.A., Noto, M.J., Park, H., Phillips, M.S., Purner, S.M., Smith, B.M., Stevens, E.N., and Varner, A.K., 2003, Use of antibiotic resistance analysis for representativeness testing of multiwatershed libraries: Applied and Environmental Microbiology, v. 69, no. 6, p. 3399-3405.

Winfield, M.D., and Groisman, E.A., 2003, Role of nonhost environments in the lifestyles of Salmonella and Escherichia coli: Applied and Environmental Microbiology, v. 69 , no. 7, p. 3687-3694.

Wood, J., Scott, K.P., Avguštin, G., Newbold, C.J., and Flint, H.J., 1998, Estimation of the relative abundance of different Bacteroides and Prevotella ribotypes in gut samples by restriction enzyme profiling of PCR-amplified 16s rRNA gene sequences: Applied and Environmental Microbiology, v. 64 , no. 10 , p. 3683-3689.

Xiao, L., Singh, A., Limor, J., Graczyk, T.K., Gradus, S., and Lal, A., 2001, Molecular characterization of Cryptosporidium oocysts in samples of raw surface water and wastewater: Applied and Environmental Microbiology, v. 67, no. 3, p. 1097-1101.

Yang, H.H., Vonopal, R.T., Grasso, D., and Smets, B.F., 2004, High diversity among environmental Escherichia coli isolates from a bovine feedlot: Applied and Environmental Microbiology, v. 70, no. 3, p. 1528-1536. 
Yoder, J.S., Blackburn, B.G., Craun, G.F., Hill, V., Levy, D.A., Chen, N., Lee, S.H., Calderon, R.L., and Beach, M.J., 2004, Surveillance for waterborne-disease outbreaks associated with recreational water-United States, 2001-2002: MMWR Surveillance Summaries, v. 53, no. 8, p. 1-22.

Zelles, L., Bai, Q.Y., Beck, T., and Beese, F., 1992, Signature fatty acids in phospholipids and lipopolysaccharides as indicators of microbial biomass and community structure in agricultural soils: Soil Biology and Biochemistry, v. 24, no. 4, p. 317-323.

\section{Glossary}

The following are definitions of some terms used in this document. Definitions presented are not intended to be universally applicable-several terms are defined in a document-specific sense.

Approach, MST approach - The choice of library-dependent or library-independent strategies to characterize sources of fecal contamination. Within library-dependent MST, the choice of population-based classification or one-to-one matching to assign individual isolates to a host species or other source category. (See also library and associated definitions, empirical type matching, population biology-based matching.)

Challenge isolates, challenge feces - Quality-control samples composed of cultivated source identifiers or knownsource feces. The source of the challenge isolates or feces is known to the compiler of the challenge but not to the analytical laboratory. Challenge materials are used to measure the internal accuracy of MST detection methods and can be used, for instance, to calculate the rate of correct classification for known-source libraries. Challenge isolates or feces differ from spikes in that they are in the same condition as the known-source library or reference material collection: the environmental matrix is excluded.

Clone - Individuals arising from a common lineage through asexual reproduction of mother cell to two daughter cells. Clones are genetically identical and, therefore, inseparable by various genetic typing methods (though they may demonstrate phenotypic differences depending on conditions).

Cosmopolitan, cosmopolitan source identifier or type - A source identifier that is found in individuals belonging to multiple host categories. Cosmopolitan source identifiers or types violate the MST assumption of host specificity.

Detection method, MST detection method - The laboratory methods used to detect or distinguish among source identifiers as part of a microbial source tracking protocol.
Empirical type matching, one-to-one matching - The strategy of assigning each isolate to a type, such that isolates of the same type appear the same by use of the typing method. Isolates of unknown source are typed and assigned to a source only if every isolate of the same type came from the same source. If the type is detected in multiple sources, the isolate of unknown origin is classified as cosmopolitan. (See also cosmopolitan.)

Fecal indicator, regulatory fecal-indicator microorganism Microorganisms that are typically found only in feces. Fecal indicators generally are not pathogenic themselves, but they indicate the potential presence of fecal pathogens. Regulatory fecal indicators are those that are written into legislation designed to establish acceptable levels of fecal contamination.

Functional gene - A gene found in a microorganism's genetic material that codes for some expressed characteristic mediating a host-microbe interaction in the preferred host but not in other hosts. An example functional gene used as a source identifier in microbial source tracking is the esp gene, encoding an adhesion factor that allows carrier strains of Enterococcus faecium to stick in the human intestine.

Genotype, genotypic profile - Characteristics that are specifically defined by the genetic sequence of the target organism, such as presence of a genetic marker or possession of identical DNA-fragment profiles.

Host category, fecal source - The category to which microbial source tracking protocols attempt to classify fecal contamination. Commonly used host classification schemes are by host species or by management category (human, wildlife, domestic livestock, or pets; human, wildlife, or domestic animals; human or nonhuman).

Inhibitor, PCR inhibitor - Chemical constituents, either from the environment (humic acids) or from the process of laboratory manipulation (ethanol) that stop the PCR from amplifying a source identifier genetic sequence and result in a false-negative result. PCR inhibitors are controlled for in laboratory analysis by adding a known PCR target (positive control) to an aliquot of the sample-if the known target is not amplified, then PCR inhibitors are present and a negative result for the source identifier does not mean that the source identifier is not present in that sample.

Isolate - A laboratory-generated culture of identical microorganisms that originated from a single cell or, in the case of conglomerates, from a colony- or plaque-forming unit.

Library, known-source library - An extensive collection of source identifiers (often bacterial isolates) used in librarydependent microbial source tracking approaches to represent fecal material from a source. 


\section{Library dependent, library-dependent MST approach} MST that requires an extensive collection of reference source identifiers from the same time and geographic location as the test samples for effective classification of test isolates.

Library independent, library-independent MST approach MST that does not require further collection of reference fecal material after the host-specificity of the source identifier has been established. The library-independent approach does, however, necessitate quality-control reference fecal material to be evaluated to ensure that the source identifier is relevant to the time and geographic location of the study setting.

Marker, host-associated or host-specific marker - A single characteristic, generally genotypic but sometimes phenotypic, used to classify results. Examples are presence of human-specific Bacteroidetes sequence and the presence of human-associated serotypes of coliphage.

Operational taxonomic unit - A measure of genetic similarity that represents some pragmatic separation of isolates but does not necessarily have phylogenetic or taxonomic meaning. In one-to-one matching, an operational taxonomic unit includes all isolates that are genetically similar at or above the level of the typing method's precision.

Phenotype, phenotypic profile - Characteristics that are specifically defined by the physiological expression of traits, such as metabolism (carbon utilization) and resistance to antibiotics.

Polymerase chain reaction, PCR - The molecular-biology method that allows amplification (reproduction) of very specific sequences of genetic material. Use of the PCR allows detection of genes or other genetic characteristics that would otherwise be undetectable because of low concentrations. The PCR is used to amplify target DNA to the point where it can be detected by other laboratory techniques.

Population-biology-based matching - A MST approach based on the hypothesis that competition in hosts with various metabolisms, basal temperatures, and gut physiologies will select for a subset of microorganisms that share some characteristics. A common example of this hypothesis is antibiotic resistance, for which only those animals that have been exposed to antibiotics (humans and domestic animals) are expected to shed gut bacteria that are resistant to particular antibiotics.

Primary habitat - The host gut; the major environment to which the source identifier is adapted to live and reproduce.

Protocol, MST protocol - A combination of source identifier, detection method, and analytical approach chosen to accomplish microbial source tracking.
Reference material, known-source reference feces - Feces, either fresh (primary habitat) or treated (secondary habitat), for which the host of origin is known. Reference material is used to build known-source libraries, to validate library-independent methods, and to estimate classification error in MST.

Resident, resident source identifier or type - A source identifier that is consistently found in an individual over time.

Sanitary survey - The critical first step in a MST evaluation, in which the contributing area to a contaminated water body is inspected for sources of the contamination. A thorough sanitary survey is necessary to determine which sources need to be included or can be excluded from a MST evaluation. In some cases, the results of the sanitary survey may be convincing enough that the MST evaluation does not need to be done.

Secondary habitat - The environment outside of the host gut; the habitat which the source identifier must survive in order to be reintroduced to a primary habitat. The secondary habitat can be either a source of fecal contamination (such as a septic field or waste lagoon) or the resource water that is contaminated. (See also tertiary habitat.)

Source identifier - Microbiological marker used as part of a microbial source tracking protocol to discriminate feces from various sources.

Speciation - Classification of microorganisms, particularly bacteria, to species as a microbial source tracking detection method. Some species (such as Enterococcus gallinarum and Rhodococcus coprophilus) were named for the habitats in which they were commonly found.

Spike sample, challenge spike - A sample submitted to the analytical laboratory in which feces or isolates from known sources are mixed into an environmental matrix (such as autoclaved river water). The source of the feces or isolates is not made known to the analytical laboratory. Spike samples are used to estimate the accuracy of microbial source tracking protocols to classify isolates to host categories after passage from the primary habitat (source environment) to the secondary habitat (resource water).

Tertiary habitat - A term sometimes used in conjunction with primary and secondary habitat. When the primary habitat is the host gut and the secondary habitat is a waste-control facility, then the resource water which is contaminated is sometimes referred to as the tertiary habitat to distinguish it from the secondary-habitat source of fecal contamination.

Total Maximum Daily Load - A provision of the Clean Water Act under which non-point sources of contamination to a water body must be identified and controlled if the water body fails to meet regulatory standards even after all point sources of contamination have been controlled.

Transient, transient source identifier or type - A source identifier that is not consistently found in an individual over time. 


\section{Appendix A: Source Identifiers}

\section{A.1 Regulatory Source Identifiers}

\section{A.1.1 Escherichia coli}

E. coli is a member of the normal intestinal flora for most warmblooded animals (Gordon and Cowling, 2003). These bacteria constitute approximately 0.1 percent of total bacteria within an adult's intestines (on a western diet; Tannock, 1995). Detection of $E$. coli is a confirmatory step in the total coliform rule for ground water, and criteria for surface water designated use attainment in many states are based, in whole or in part, on E. coli concentrations. The USEPA required that all states initiate $E$. coli or enterococci-concentration-based monitoring for recreational waters by April 2004 (U.S. Congress, 2000). Though they have been recommended by the USEPA since 1984 for recreational water-quality assessment (for freshwaters), E. coli are bacteria; therefore, they may not adequately represent transport and survival characteristics of protozoan and viral pathogens.

E. coli are gram-negative, facultatively anaerobic bacteria that ferment lactose and grow at temperatures up to $44.5^{\circ} \mathrm{C}$. They are commonly detected by colony growth on the media mTEC, modified mTEC, MI, or the combination of MENDO and NA-MUG agars after membrane filtration. E. coli also can be detected in a most-probable-number format by use of, for instance, the commercial Colilert and Colitag systems. Immunological and PCR-based tests also have been proposed for E. coli detection and quantification. Confirmation of $E$. coli is typically achieved through biochemical tests or enzymatic assays. In clinical applications, the most commonly used confirmatory tests are collectively known as $\mathrm{IMViC}$-indole production, methyl red reaction, Voges-Proskauer test, and failure to grow on citrate-minimal media. In research labs, it is common to use the Analytical Profile Index (API) biotyping system (22 biochemical tests) or Biolog GN plates (95 sole-source substrates) or simply to test for MUG (4-methylumbelliferyl-ß3D-glucuronide) hydrolysis (a test for $\beta$-glucuronidase activity). For recreational waters, tests for indole production, gas formation on lactose, failure to express urease, failure to express oxidase, and failure to grow on citrate-minimal media are the recommended confirmation tests (U.S. Environmental Protection Agency, 2000a). There is a need for standardization of E. coli detection and confirmation methods among MST researchers because each of the listed media and confirmation tests excludes some portion of the entire E. coli population.

\section{A.1.2 Enterococci}

Like E. coli, enterococci are members of the normal intestinal flora for most, if not all, warmblooded animals. The enterococci are non motile, gram-positive cocci that are found in mammals, birds (Wheeler and others, 2002), plants (Ott and others, 2001), fish, and insects (Kanoe and Abe, 1988). They predominate in the gastrointestinal tract and occur less commonly in the genitourinary tract and the oral cavity of animals. Enterococci survive longer in marine environments (Cabelli and others, 1982) and through water treatment processes (Miescier and Cabelli, 1982) than coliforms do. Numbers in recreational waters correlate with the risk of gastrointestinal illness better than E. coli (Cabelli and others, 1982; Turbow and others, 2003). Though they have been recommended by the USEPA since 1984 for recreational water-quality assessment (for both fresh and marine waters) enteroccocci are bacteria; therefore, they may not adequately represent transport and survival characteristics of protozoan and viral pathogens.

Enterococci are differentiated from other fecal streptococci by their ability to grow in 6.5 percent $\mathrm{NaCl}$, at $\mathrm{pH} 9.6$, and at $10^{\circ} \mathrm{C}$ and $45^{\circ} \mathrm{C}$; they fail to express catalase, and they create a black precipitate on esculin iron agar (EIA agar; U.S. Environmental Protection Agency, 2000a) or exhibit ß-D glucosidase activity (mEI agar; Rhodes and Kator, 1997; U.S. Environmental Protection Agency, 2000a). The enterococci were previously classified as Group D streptococci, 
because they contain a group-D-specific cell wall carbohydrate (glycerol teichoic acid) linked to the cytoplasmic membrane. The group includes as members the species Enterococcus faecalis, E. faecium, E. avium, E. gallinarum, and E. durans.

Enterococci are commonly detected by colony growth after membrane filtration using $\mathrm{mEI}$ agar or the combination of $\mathrm{mE}$ and EIA agars. Enterococci also can be detected in a most-probable-number format by use of, for example, the commercial Enterolert system. Standard maintenance growth conditions include incubation on brain heart infusion (BHI) or similar broth or agar at $35-37^{\circ} \mathrm{C}$ without aeration (U.S. Environmental Protection Agency, 2000a).

\section{A.1.3 Coliphage}

Coliphage are bacteriophages (viruses) that infect E. coli and, to a lesser extent, other coliform bacteria (Furuse, 1987). Because their presence is directly related to the presence of $E$. coli (Borrego and others, 1987), coliphage have been proposed as superior fecal-indicator microorganisms. Coliphage are generally divided into somatic and F-specific types, based on their site of infection on the E. coli cell. F-specific RNA coliphage serve as model indicators of enteric viruses in freshwater (Havelaar, 1993), an area where E. coli is deficient as a model organism (Borchardt and others, 2003). Coliphage may be promulgated formally as regulatory fecal indicators for ground water in the United States under the proposed Ground Water Rule (U.S. Environmental Protection Agency 2000c).

Coliphage is an operational taxonomic unit that includes distinct bacteriophage of multiple taxa. As noted above, the taxa correspond to somatic and F-specific coliphage. Somatic coliphage (at least four families, all DNA based) use a lipopolysaccharide on the $E$. coli cell outer surface as a recognition factor to initiate infection. F-specific coliphage use antigens on the F-pilus (used for sexual exchange of genetic material between $E$. coli cells) to initiate infection. F-specific coliphage include those that use DNA as their genetic material (Inoviridae) and those that use single-stranded RNA as their genetic material (Leviveridae; Vinje and others, 2004). F-specific RNA-based coliphage have been subdivided into four groups based on serotyping (Furuse, 1987) and genotyping (Beekwilder and others, 1996; Hsu and others, 1995; Vinje and others, 2004). Groups I and IV are most commonly found in nonhuman hosts, and groups II and III are most commonly found in human hosts (Cole and others, 2003).

Coliphage are detected by the presence of plaques (areas of no growth) on a lawn of $E$. coli host bacteria. Different host strains of E. coli are used for somatic and F-specific coliphage. Detection methods typically follow USEPA method 1601 (presence-absence) or method 1602 (quantification). In method 1601, host E. coli are added to a water sample to allow coliphage reproduction, and the resulting enrichment is spotted onto a plate previously inoculated with the same host $E$. coli. Formation of a plaque around the spot indicates the presence of coliphage in the sample. In method 1602, the water sample is combined with host $E$. coli and molten nutrient agar. During incubation, a plaque forms in the E. coli lawn where an infectious coliphage particle was embedded in the agar gel, leading to a count of plaque-forming units.

\section{A.1.4 Fecal Coliforms}

Fecal coliform is an operational taxonomic unit that includes E. coli. Many states historically used fecal coliform concentrations as their primary indicator of bacterial water quality. As "thermotolerant coliforms," the fecal coliform group was established as an alternative to total coliforms to detect organisms exclusively of fecal origin. The group includes species other than E. coli, including some that have environmental origins and some with a potential for regrowth in the environment. In a landmark epidemiology study, USEPA (Dufour, 1984) did not find a good relation between health risk and fecal coliform concentrations; therefore, since 1986, USEPA has recommended the use of other indicator organisms to monitor for bacteriological water quality (U.S. Environmental Protection Agency, 1986). Fecal coliforms are all gram-negative, facultatively anaerobic bacteria that ferment lactose with gas production and grow at temperatures up to $44.5^{\circ} \mathrm{C}$. They are commonly detected by colony growth after membrane filtration using $\mathrm{mFC}$ agar. 


\section{A.1.5 Total Coliforms}

Total coliform is an operational taxonomic unit that includes $E$. coli and fecal coliforms. Total coliform concentrations have been used to monitor drinking-water sources for almost 100 years because they are seen as a more conservative indication of fecal contamination than $E$. coli or fecal coliforms. The total coliform group encompasses 19 genera (including Escherichia, Klebsiella, Enterobacter, and Citrobacter) and 80 species (Leclerc and others, 2001). Coliforms reside in the intestinal tract of humans and animals, but also occur naturally in soil, surface water, fish, mollusks, leafy plants, insects, and rodents. This is one reason that total coliforms are generally considered poor indicators of fecal contamination and health risk (Borrego and others, 1987). Total coliforms are used in the Ground Water Rule as an initial indication of fecal contamination (U.S. Environmental Protection Agency, 2000c). Total coliforms are gram-negative, aerobic or facultatively anaerobic, nonsporulating bacteria that ferment lactose at $35^{\circ} \mathrm{C}$ within 48 hours. Total coliforms are commonly detected by colony growth after membrane filtration using mENDO or MI agar. Total coliforms also can be detected in a most-probable-number format by use of, for example, the commercial Colilert system.

\section{A.2 Nonregulatory Source Identifiers}

\section{A.2.1 Ratios of Microbes}

One of the earliest approaches to MST involved use of the ratio of fecal coliforms to fecal streptococci (Geldreich and Kenner, 1969). Use of these ratios eventually was deemed unreliable because of the variable survival rates of the bacterial species involved (Clesceri and others, 1998). Refer to section 4.4 for further details.

\section{A.2.2 Host-Specific Bacteria}

Several source identifier bacterial species currently are used for MST. Enterococcus faecalis may have a host range limited to humans and a few other animals (dogs and chickens; Pourcher and others, 1991). Wheeler and others (2002) concluded that combining speciation of Ent. faecalis with ribotyping was a useful approach for identifying human-source contamination. Rhodococcus coprophilus is found primarily in wheat straw and, therefore, is most commonly detected in the feces of grazing animals such as cattle (Sinton and others, 1998). Two Bifodobacterium species, $B$. adolescentis and $B$. dentium, have a narrow host range that is dominated by humans (Bonjoch and others, 2004).

\section{A.2.3 Host-Specific Viruses}

Adenoviruses have been proposed as an index of human viruses (Jiang and others, 2001; Piña and others, 1998). Enteroviruses have been found in activated sludge, sewage outfalls, and fresh and marine waters associated with human fecal contamination (Kopecka and others, 1993; Reynolds and others, 1998; Griffin and others, 1999; Noble and Fuhrman, 2001; Jiang and others, 2001). Both adenoviruses and enteroviruses have been evaluated and recommended for MST; however, it appears that they are limited to identifying human contamination originating from populations, rather than from individuals (Noble and others, 2003).

Bovine enteroviruses (Ley and others, 2002) and bovine and porcine adenoviruses (Maluquer de Motes and others, 2004) also have been proposed to detect animal-source fecal contamination. Similarly, teschoviruses have been used as an indicator of porcine fecal contamination (Jiménez-Clavero and others, 2003). 


\section{A.2.4 Host-Specific Genetic Markers}

Genetic markers are sometimes used to detect host-specific microorganisms or types. These markers are often genes or other fragments of DNA that can be multiplied from within a mix with other DNA by the polymerase chain reaction. Once the marker has been multiplied, it can be detected by gel electrophoresis or with labeled probes. Many references describe these and other molecular techniques. The reader is directed to Persing and others (1993) as one such reference.

\section{A.2.4.1 DNA Coding16S Ribosome of Bacteroides/Prevotella Group Anaerobes}

Source-specific Bacteroidetes sequences have been identified by means of terminal restriction fragment length polymorphism (t-RFLP), length heterogeneity PCR, or subtractive hybridization, and used to design PCR primers for MST (Bernhard and Field, 2000a,b). The length heterogeneity PCR primer pairs have been field tested (Bernhard and others, 2003) and they produced relatively accurate results for identification of human and ruminant contamination in a methods comparison study (Field and others, 2003). Primer pairs for additional host species are under development (Dick and others, 2002).

\section{A.2.4.2 Toxin Genes of Pathogenic Escherichia coli}

PCR assays have been developed that target the heat-stable enterotoxin STIb to identify human fecal contamination (Oshiro and Olson, 1995), the heat-labile enterotoxin LTIIa to identify cattle fecal contamination (Khatib and others, 2002), and the heat-stable enterotoxin STII to identify swine fecal contamination (Khatib and others, 2003).

\section{Appendix B: Detection Methods}

\section{B.1 Conventional Typing Methods}

\section{B.1.1 Speciation}

\section{Method}

Microbiologists first divided bacteria into species on the basis of phenotypic information such as cell morphology and physiology. Suites of biochemical tests that facilitate classification of bacteria to species are described in "Bergey's Manual of Systematic Bacteriology" (Atlas, 1988). Classical approaches to bacterial systematics have been challenged by the advent of phylogenetics, which reveals an evolutionary basis for species definition (Stackebrandt, 2003). Still, the guiding principle for species definition is 70 percent DNA-DNA homology, a threshold that leaves considerable room for variability within species (Maynard Smith and others, 2000).

Viruses, on the other hand, were referred to until recently simply by their common names (for example, poliovirus). Formal classification is now based on nucleic acid type, particle size, shape and structure, and mode of replication (Atlas, 1988). Classification of protozoa follows more closely the model of macrobiology: as eukaryotes, protozoa fit within the traditional definition of species.

\section{Information Content}

Speciation has a long history of use in classification. Host specificity has influenced speciation with effects ranging from incidental in the case of commensals to integral in the case of some pathogens. 
Speciation is significant to the many forms of MST that start with a basic taxonomic unit (often the species) as a means of separating out extraneous information. Reports indicate that Bacteroides fragilis bacteriophage (Tartera and others, 1989), at least one species within Enterococcus (Wheeler and others, 2002), and Cryptosporidium species (Ong and others, 2002) are specific to host sources.

\section{B.1.2 Serotyping}

\section{Method}

Serotyping was among the first subtyping methods developed for identification of pathogenic strains. Serotyping has been applied extensively to organisms that are now used for source tracking, including E. coli. In serotype analysis, antibodies to cell-surface antigens are added to a suspension. If the antibody matches the target antigen, the suspension agglutinates (clumps), and the reaction is positive. For many gram-negative bacteria, series of antibodies have been defined against cell-surface lipopolysaccharides ( $\mathrm{O}$ antigens) and flagellar proteins ( $\mathrm{H}$ antigens). These results often are reported in conjunction, as in E. coli $\mathrm{O} 157: \mathrm{H} 7$. In addition to the $\mathrm{O}$ and $\mathrm{H}$ antigens, capsular ( $\mathrm{K}$ antigens) sometimes are used in serotyping. The method for serotyping coliphage differs in mechanism but not principle (Hsu and others, 1995).

\section{Information Content}

The information gained from serotyping is limited by the finite number of tested antigens and the reactions expressed by that isolate against the suite of antigen tests. Expression of cellsurface antigens is a stable characteristic. The $\mathrm{O}: \mathrm{H}$ scheme of serotyping E. coli includes $170 \mathrm{O}$ antigens and $55 \mathrm{H}$ antigens, with more than 9,000 possible serotypes (Bettelheim and Thomas, 2004). Not all strains can be serotyped.

Surface antigens are an important component of host-microbe interactions. As such, there may be a functional link between surface antigen expression and adaptation to succeed in a host (Toivanen and others, 2001). Enterotoxigenic E. coli associated with specific hosts have been defined by serotype (O:H) or serogroup (O only) conventions (Bettelheim and Thomas, 2004). Early studies of the stability of $E$. coli lineages in the human gastrointestinal tract also made use of serotyping (Sears and Brownlee, 1952). See the review by Scott and others (2002) and the investigation by Parveen and others (2001) for descriptions of bacterial serotyping as used in source tracking investigations. Serotypes of the viral fecal-indicator $\mathrm{F}^{+} \mathrm{RNA}$ coliphage also have been evaluated for use in source tracking (Furuse, 1987).

\section{B.1.3 Multilocus Enzyme Electrophoresis}

\section{Method}

Multilocus enzyme electrophoresis (MLEE) has been used extensively in ecological studies to track populations of organisms. To perform MLEE, pure cultures of organisms are grown out, and enzymes are separated by electrophoretic mobility. Isolates demonstrating different enzyme mobilities are termed electrophoretic types (ETs).

\section{Information Content}

The enzymes used in MLEE are generally housekeeping enzymes, those essential for cell function. Substitutions of amino acids in the primary enzyme structure may not affect enzyme function but can result in altered electrophoretic mobility. Because primary enzyme structure is directly related to genetic information, MLEE data often are reported as representing genotypic rather than phenotypic information.

MLEE may be useful for MST using either the 1:1 matching strategy or the population genetics strategy because there is a known basis for similarity among ETs. MLEE data have 
been used to evaluate $E$. coli in studies related to source tracking (Caugant and others, 1984; Gordon, 2001; Gordon and others, 2002; and Souza and others, 1999)

\section{B.2 Phenotypic Methods}

\section{B.2.1 Carbon Utilization Profiles}

\section{Method}

To generate carbon utilization profiles, pure cultures of a strain are inoculated into test solutions containing a single carbon source. Growth of the test strain causes some observable change in the medium, which is scored as presence or absence of substrate utilization.

\section{Information content}

Presence or absence of carbon utilization ability has been criticized as an unstable or variable characteristic in bacterial strains (Tenover and others, 1997). Commercial substrate suites were developed to discriminate among species but may not have ecological significance, hindering data interpretation. Carbon utilization profiles using pure cultures of indicator organisms have been proposed as a viable approach for MST (Hagedorn and others, 2003).

\section{B.2.2 Membrane Fatty Acids}

\section{Method}

The membranes of bacteria contain phospholipids that are crucial factors controlling cell permeability. To analyze the phospholipids, cell cultures are first saponified, then resultant fatty acids are extracted into an organic phase. Free fatty acids are then methylated, purified, and concentrated. Concentrated extracts are analyzed by gas chromatography. This variant of phospholipid fatty acid analysis is called gas chromatography fatty acid methyl ester (GC-FAME) analysis.

\section{Information Content}

Phospholipid composition information has been applied to the evaluation of microbial community composition in agricultural soils and other settings. Signature fatty acids have been proposed that indicate the presence of specific groups of microorganisms (Zelles and others, 1992) on the basis of fatty acid function in the cell membrane.

Parveen and others (2001) included GC-FAME analysis in their continuing characterization of a collection of $E$. coli used for source tracking and found no relation between FAME profile and isolate source. No other published reports have been found in the literature.

\section{B.2.3 Antibiotic Resistance}

\section{Method}

Bacteria routinely are characterized by their sensitivity or resistance to antibiotics in clinical use. Many permutations of clinical antibiotic resistance methods have been developed in research laboratories. In clinical use, two standardized methods are the Kirby-Bauer test and multi-antibiotic resistance profiling using the National Committee for Clinical Laboratory Standards (NCCLS) to define clinical resistance.

The Kirby-Bauer test is done by placing a panel of paper disks impregnated with different antibiotics on the surface of a plate seeded with a test strain. Results are recorded as diameter of 
growth inhibition after incubation for a standardized amount of time at a specified temperature. The diameter of growth inhibition is related to the degree of antibiotic sensitivity because of a diffusion-induced concentration gradient of antibiotic in the agar.

Clinical profiling for multiple antibiotic resistance is done by use of Mueller-Hinton agar fortified with known concentrations of chosen antibiotics. Each concentration of each antibiotic in the test panel is represented in a separate agar plate. Standardized inocula of test isolates are placed on each plate, usually with a replica plater.

\section{Information Content}

Information from antibiotic-resistance-based methods has logical value when source categories are exposed to different antibiotics. An example might be where differentiation was needed between feces from a population of cattle, which had been exposed to one antibiotic, and a population of swine, which had been exposed to a different antibiotic.

Many researchers have reported the ability of experimental antibiotic resistance methods to separate isolates obtained from animal sources (Graves and others, 2002; Hagedorn and others, 1999; Harwood and others, 2000; Parveen and others, 1997; Wiggins and others, 1999). Two experimental variants on antibiotic sensitivity testing have been used extensively in pursuit of source tracking. Multiple antibiotic resistance analysis (MAR; Parveen and others, 1997) tests each isolate against a single concentration of each antibiotic in the panel. The antibiotics and concentrations in the panel were developed to reflect antibiotic use in humans and domestic animals. Antibiotic resistance analysis (ARA; Wiggins, 1996) challenges each isolate against multiple concentrations of antibiotics, the concentrations of which are chosen on the basis of ability to separate isolates from different hosts rather than the NCCLS standards. Information generated by the Kirby-Bauer method has been demonstrated in one study to be ineffective for MST using E. coli (Hagedorn, 1999); however, its use continues to be investigated (J. Mott, Texas A\&M University, Corpus Christi, Tex., oral commun., November 2004). A modification of ARA, in which multiple concentrations of antibiotic are used to calculate an antibiotic resistance index representative of a fecal-source population, also has been used for MST (D.S. Francy, U.S. Geological Survey, Columbus, Ohio, oral commun., December 2004).

\section{B.3 Genotypic Methods}

Genotypic methods are represented by multiple approaches in three major categories: evaluation of similarity based on the whole genome, evaluation of similarity based on genes present in all target organisms, and direct evaluation of source based on presence or absence of a DNA sequence. Within these three major categories exist a wide array of sometimes overlapping protocols. Where possible, each is discussed separately.

Many of the genotypic methods were developed in the context of epidemiology or systematics. Several reviews present in-depth discussion of these methods, including those by Louws and others (1999), Olive and Bean (1999), Struelens (1998), Tenover and others (1997), and van Belkum and others (2001).

\section{B.3.1 Similarity Based on Whole Genome Analysis}

\section{B.3.1.1 Macrorestriction Digest Pulsed-Field Gel Electrophoresis (PFGE)}

\section{Method}

In PFGE, extracted chromosomal DNA is purified and digested by an infrequently cutting restriction enzyme, resulting in some 10 to 30 large fragments. The sum of all fragment lengths can be used to estimate the size of the chromosome. Fragments are separated by PFGE in a specialized rig. Banding patterns are visualized by staining, and fragment sizes are estimated by comparison with a ladder of known molecular weight DNA standards. 


\section{Information Content}

PFGE is the standard against which other methods are compared in many epidemiological investigations. The method is described as "superior to most other methods for biochemical and molecular typing" (Olive and Bean, 1999). Interpretation of similarity is possible because each change in banding pattern can be related to a genetic event.

Parveen and others (2001) evaluated PFGE data by means of discriminant analysis and found no relation between fragment pattern and source when the restriction enzyme SfiI was used to digest. Simmons and others (2000), however, reported success when applying PFGE typing to MST using 1:1 association of unknown patterns with source patterns. Current usage is to restrict with NotI following Simmons and others (2000) or XbaI following the CDC PulseNet protocol for PFGE (Centers for Disease Control and Prevention, 1996).

\section{B.3.1.2 Amplified Fragment Length Polymorphism Analysis (AFLP)}

\section{Method}

AFLP is a partial-genome analogue to PFGE. Whole chromosomal DNA is digested by both a frequently cutting and an infrequently cutting restriction enzyme. An adapter is ligated onto the sticky end left by the infrequently cutting restriction enzyme, and PCR is done using a primer complementary to the adapter sequence. If fewer bands are desired, the primer can be designed to overhang the cut site by a single base, effectively reducing amplification to one in four possible products. PCR products are separated by agarose gel electrophoresis and visualized by staining (Savelkoul and others, 1999).

\section{Information Content}

The information generated by AFLP may represent the whole-genome similarity of two strains but may not be indicative of phylogenetic relatedness. Use of this method has not been frequently reported in the source-tracking literature. One report on AFLP utility for MST studies (Guan and others, 2002) is available in the literature, and further work is ongoing.

\section{B.3.1.3 Repetitive Element PCR (Rep-PCR)}

\section{Method}

Repetitive elements have been observed and described in many bacteria. Some of these repeated elements flank transposable elements (insertion sequences; Smith-Keary, 1989), and others are present at high frequency but have unknown function (Stern and others, 1984). The rep-PCR method uses primers for these repetitive sequences to generate PCR products representing DNA between proximal, facing repetitive sequences. Besides the insertion sequences, primers for three conserved motifs in bacterial repetitive elements are used for rep-PCR; namely, REP (repetitive extragenic palindromic sequence), ERIC (enterobacterial repeating intragenic consensus sequence), and BOX (named after the boxes drawn around candidate sequences in early research).

\section{Information Content}

Bands generated by rep-PCR represent cryptic DNA fragments-the only thing that is known is that each band has the repetitive element at each end. Changes in banding patterns could be caused by a variety of genetic events, hindering interpretation of band pattern similarity. DNA amplification products represent a small fraction of the genome.

Variants of the rep-PCR method should be applicable to any microorganism having repeated sequences in its genome. In the past, the methods have been used to type plant pathogens (Rademaker and de Bruijn, 1997). Olive and Bean (1999) reported that rep-PCR was quickly becom- 
ing a widely used typing protocol because of its discriminatory power, ease of application, and low cost.

Dombek and others (2000) reported that rep-PCR using the BOXA1R primer had utility for source tracking. Carson and others (2003) reported performance of rep-PCR using the BOXA1R primer that was equal or superior to the performance of ribotyping by use of the HindIII restriction enzyme.

\section{B.3.2 Similarity Based on Analysis of Specific Genes}

Methods similar to the whole-genome-based methods are sometimes used with defined genes in an attempt to generate more readily interpreted similarity data. The genes chosen tend to have functional relevance, such as ribosomal RNA operons and toxin genes.

\section{B.3.2.1 Ribotyping and Other Restriction Fragment Length Polymorphism (RFLP)-Type Methods}

\section{Method}

The ribotyping procedure begins by extracting and purifying whole chromosomal DNA from a pure culture. Purified DNA is digested by a frequently cutting restriction enzyme. Digested DNA fragments are separated by agarose gel electrophoresis. If the DNA is visualized at this stage, it appears as a smear of DNA fragments on the gel. Digested, separated DNA fragments are blotted from the gel onto a nylon membrane (the Southern blot procedure). The DNA is fixed in space on the nylon membrane by UV cross-linking. Fragments containing DNA encoding 5S, 16S, and/or 23S rRNA are detected by hybridization with radiolabeled universal rDNA probes or digoxigenin-labeled probes. Ribotype exposures can be inspected visually or scanned into image analysis software (Olive and Bean, 1999).

Other variants of the RFLP protocol are accomplished similarly with probes for other genes of interest. For more information about alternate RFLP protocols, refer to Olive and Bean (1999) and Tenover and others (1997).

\section{Information Content}

Some of the information generated by ribotyping is based on differences within the rRNA operon and is therefore conserved in related strains. The terminal fragments, however, extend outside of the operon into the nonconserved region of the genome. As such, similarity of ribotypes does not necessarily relate directly to whole-genome or phylogenetic similarity.

Ribotyping protocols using $E$. coli are among the most common means of accomplishing source tracking (Carson and others, 2001; Jenkins and others, 2003; Parveen and others, 1999; Samadpour and Chechowitz, 1995; Scott and others, 2003). In past MST studies, the enzyme used generally has been HindIII for the single digest technique (for example, Parveen and others, 1999) or EcoRI and $P v u I I$ for the double digest technique (for example, Samadpour and Chechowitz, 1995).

\section{B.3.2.2 Amplified Ribosomal DNA Restriction Analysis (ARDRA) and Other PCR-RFLP Methods}

\section{Method}

In PCR-RFLP methods, variation in a specific gene is detected by gene amplification using PCR followed by restriction of the amplicon with a frequently-cutting restriction enzyme. Minor variations in the sequences of functional genes can be detected by PCR-RFLP. The ARDRA analysis is the variant of PCR-RFLP based on amplification of the rRNA operon. (Olive and Bean, 1999; Vaneechoutte and Heyndrickx, 2001). 


\section{Information Content}

Interpretation of differences in the amplified gene is facilitated by the presumed or known function of the gene sequence evaluated. Though theoretically suitable, use of ARDRA and other PCR-RFLP methods is not commonly reported in the MST literature.

\section{B.3.2.3 Terminal Restriction Fragment Length Polymorphism (t-RFLP)}

\section{Method}

The t-RFLP method can be thought of as a further specialized application of PCR-RFLP. As in PCR-RFLP, a gene sequence of presumed or known function is amplified by PCR. In this case, however, one primer is labeled such that only a terminal restriction fragment is visualized, resulting in only one bit of information for each gene copy within each strain evaluated. The terminal fragment can be sequenced, or the pattern of terminal fragments can be observed by capillary electrophoresis in the sequencer. This method more often is used to characterize communities of microorganisms rather than individual strains (Bernhard and Field, 2000a).

\section{Information Content}

Data are generated by t-RFLP without the need for cultivation of isolates; therefore, this method has found utility for community comparisons. Fragment size information generated by t-RFLP does not have functional or phylogenetic significance, though sequencing information may have significance.

Bernhard and Field (2000b) sequenced signature t-RFLP peaks prevalent in host sources to enable their design of host-specific PCR primers against Bacteroides-Prevotella. Ongoing research by others in the field investigates the use of Bacteroides-Prevotella marker profiles to indicate the origin of fecal contamination (Seurinck and others 2005).

\section{B.3.3 Typing by Marker Sequence Presence or Absence}

\section{B.3.3.1 Coliphage Genotyping and Other Dot Blot Analyses}

\section{Method}

To genotype coliphage, RNA is fixed to a nylon membrane and challenged against each of four labeled probes. The probes could be labeled either radioactively or with digoxigenin for chemiluminescent detection. Successful hybridization with one of the four probes indicates the type of the coliphage (Hsu and others, 1995). Comparable probes could be developed for other applications. A reverse line blot hybridization method, in which the probes are fixed to the nylon membrane and tested against each isolate, uses essentially the same principle and promises to have higher throughput than traditional dot blot hybridization (Vinje and others, 2004)

\section{Information Content}

A great deal of prior knowledge is required to ensure that hybridization with a probe adequately represents the type. In the example of coliphage, types were defined on the basis of serological reactions, and the probes developed are surrogates for that information. Genotyping

coliphages was reported to be a useful method of categorizing coliphage into the groups used for source tracking (Calci and others, 1998; Schaper, Duran, and Jofre, 2002; Schaper, Jofre, and others, 2002). 
B.3.3.2 Length-Heterogeneity PCR (LH-PCR) for Escherichia coli Toxin Genes and Bacteroides-Prevotella Group Markers

\section{Method}

LH-PCR is a method whereby a sequence of interest is amplified by PCR and resolved by agarose gel electrophoresis. Prior knowledge about specificity of the primer and expected amplicon size is required for interpretation of amplified product (Simpson and others, 2002).

\section{Information content}

Production of the desired product using a specific primer or primer set indicates the presence of the target sequence. Confirmation can be done by sequencing or probing the product by dot blot analysis.

This method should be applicable to a wide range of source identifiers provided that sufficient prior knowledge of products is available. LH-PCR provides an alternative to dot blotting to detect specific gene sequences from mixed DNA. Primers have been developed to detect Bacteroides-Prevotella types associated with different hosts (Bernhard and Field, 2000b) and to detect the presence of host-specific toxin genes in E. coli (Khatib and others, 2002). 
Table 2: Summary of how various microbial source tracking (MST) source identifiers meet generalized assumptions for application.

[More extensive details are presented in the text]

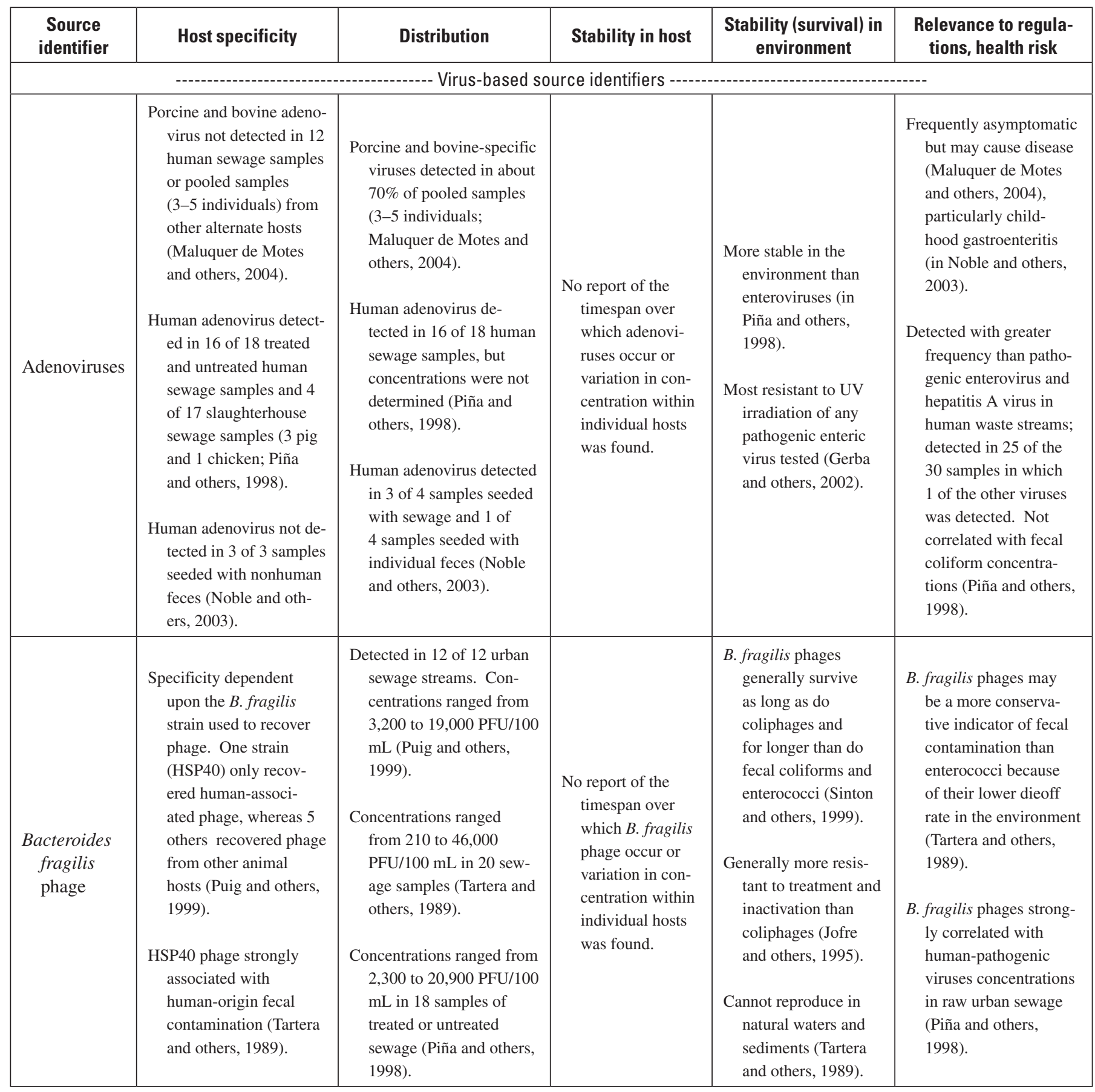


Table 2: Summary of how various microbial source tracking (MST) source identifiers meet generalized assumptions for application.Continued

[More extensive details are presented in the text]

\begin{tabular}{|c|c|c|c|c|c|}
\hline $\begin{array}{l}\text { Source } \\
\text { identifier }\end{array}$ & Host specificity & Distribution & Stability in host & $\begin{array}{c}\text { Stability (survival) in } \\
\text { environment }\end{array}$ & $\begin{array}{l}\text { Relevance to regula- } \\
\text { tions, health risk }\end{array}$ \\
\hline $\begin{array}{l}\text { Coliphage } \\
\text { (genotypes) }\end{array}$ & $\begin{array}{l}\text { Types reported to } \\
\text { indicate human (II, } \\
\text { III) and nonhuman (I, } \\
\text { IV) sources of fecal } \\
\text { contamination (Furuse, } \\
\text { 1987). } \\
\text { Types differentially } \\
\text { distributed among } \\
\text { hosts (Cole and others, } \\
\text { 2003). } \\
\text { Human types II and III } \\
\text { found in } 16 \text { of } 16 \\
\text { sewage samples and } \\
\text { 17 of } 29 \text { pig samples. } \\
\text { Nonhuman types I, } \\
\text { IV found in } 0 \text { of } 16 \\
\text { sewage samples and } \\
74 \text { of } 91 \text { chicken and } \\
\text { pig samples (Hsu and } \\
\text { others, 1995). } \\
\text { Human type III coli- } \\
\text { phages detected (23 of } \\
31 \text { isolates were type } \\
\text { III) in composited gull } \\
\text { feces (Noble and oth- } \\
\text { ers, 2003) and poultry } \\
\text { feces (Schaper, Jofre, } \\
\text { and others, 2002). } \\
\text { Human type II coliphages } \\
\text { were detected in hu- } \\
\text { man, cattle, poultry, } \\
\text { and pig feces, though } \\
\text { nonhuman type I and } \\
\text { IV were not detected in } \\
\text { human feces (Schaper, } \\
\text { Jofre, and others, } \\
\text { (2002) }\end{array}$ & $\begin{array}{l}\text { Concentration and distribu- } \\
\text { tion both vary by host; } \\
\text { where detected, concen- } \\
\text { tration varies by } 2 \text { orders } \\
\text { of magnitude (Calci and } \\
\text { others, 1998). } \\
\text { Detected in } 5 \text { of } 14 \text { hosts } \\
\text { tested (human, swine, } \\
\text { cattle, gull, goose); } \\
\text { where detected, concen- } \\
\text { tration varies by } 3 \text { orders } \\
\text { of magnitude (Cole and } \\
\text { others, } 2003 \text { ). } \\
\text { Never detected in feces of } \\
\text { nine hosts, though pres- } \\
\text { ent in local water (Grif- } \\
\text { fin and others, } 2000 \text { ). } \\
\text { Isolated from about } 10 \% \text { of } \\
\text { individual humans and at } \\
\text { generally higher rates (to } \\
70 \% \text { ) from nonhumans } \\
\text { (Schaper, Jofre, and oth- } \\
\text { ers, } 2002 \text { ). } \\
\text { Human types II and III de- } \\
\text { tected in } 5 \text { of } 7 \text { samples } \\
\text { seeded with sewage } \\
\text { but only } 1 \text { of } 9 \text { samples } \\
\text { seeded with individual } \\
\text { feces (Noble and others, } \\
2003 \text { ). }\end{array}$ & $\begin{array}{l}\text { No report of the } \\
\text { timespan over } \\
\text { which coliphages } \\
\text { occur or variation } \\
\text { in concentration } \\
\text { within individual } \\
\text { hosts was found. }\end{array}$ & $\begin{array}{l}\text { Type I more resistant } \\
\text { to inactivation than } \\
\text { Type II; Types III } \\
\text { and IV more suscep- } \\
\text { tible to inactivation } \\
\text { than types I and II } \\
\text { (Schaper, Duran, } \\
\text { and Jofre, 2002). } \\
\text { F+ coliphages gener- } \\
\text { ally survive longer } \\
\text { in the environ- } \\
\text { ment than do fecal } \\
\text { coliforms and } \\
\text { enterococci (Sinton } \\
\text { and others, 1999). }\end{array}$ & $\begin{array}{l}\text { The proposed Ground } \\
\text { Water Rule uses detec- } \\
\text { tion of any coliphages } \\
\text { to indicate fecal } \\
\text { contamination, not } \\
\text { specifically F+ RNA } \\
\text { coliphages. The inci- } \\
\text { dence or concentration } \\
\text { of F+ RNA coliphage } \\
\text { was not consistently } \\
\text { related to the concen- } \\
\text { tration of coliphage in } \\
\text { general in the support- } \\
\text { ing information for the } \\
\text { Ground Water Rule } \\
\text { (U.S. Environmental } \\
\text { Protection Agency, } \\
\text { 2000c). }\end{array}$ \\
\hline
\end{tabular}


Table 2: Summary of how various microbial source tracking (MST) source identifiers meet generalized assumptions for application.Continued

[More extensive details are presented in the text]

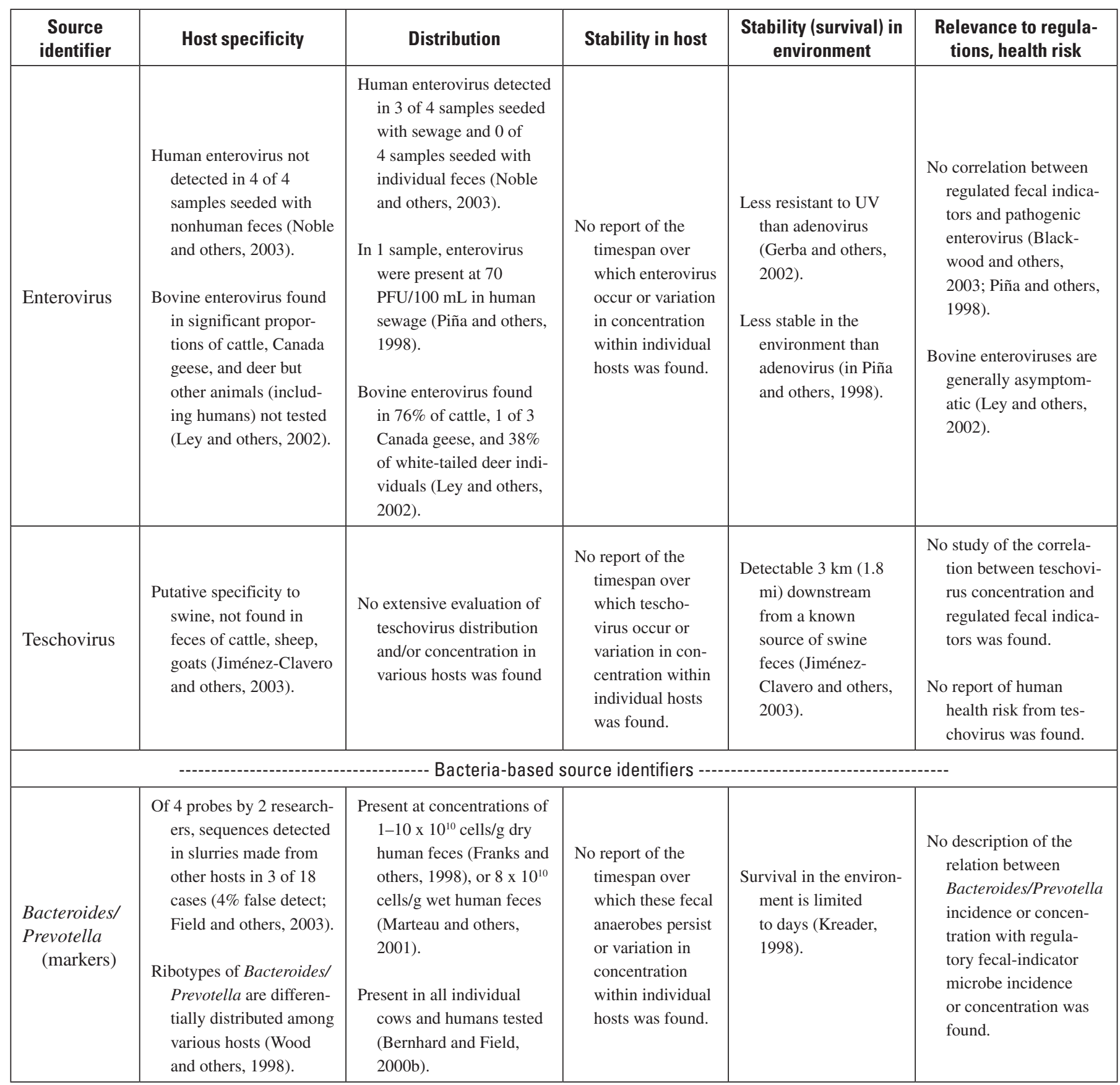


Table 2: Summary of how various microbial source tracking (MST) source identifiers meet generalized assumptions for application.Continued

[More extensive details are presented in the text]

\begin{tabular}{|c|c|c|c|c|c|}
\hline $\begin{array}{l}\text { Source } \\
\text { identifier }\end{array}$ & Host specificity & Distribution & Stability in host & $\begin{array}{c}\text { Stability (survival) in } \\
\text { environment }\end{array}$ & $\begin{array}{c}\text { Relevance to regula- } \\
\text { tions, health risk }\end{array}$ \\
\hline $\begin{array}{l}\text { Bifidobacte- } \\
\quad \text { rium } \\
\text { species }\end{array}$ & $\begin{array}{l}\text { Twelve species are known } \\
\text { to inhabit the human } \\
\text { gastrointestinal tract } \\
\text { (in Satokari and others, } \\
\text { 2001). } \\
\text { B. dentium, B. adoles- } \\
\text { centis, and B. longum } \\
\text { found exclusively in } \\
\text { human-origin sewage; } \\
5 \text { other species dif- } \\
\text { ferentially distributed. } \\
\text { Limited (3 of 19) } \\
\text { detections in slaugh- } \\
\text { terhouse waste streams } \\
\text { (Bonjoch and others, } \\
\text { 2004). } \\
\text { Sorbitol-fermenting types } \\
\text { found only in humans } \\
\text { and pigs of } 11 \text { hosts } \\
\text { tested (Mara and Ora- } \\
\text { gui, 1983). }\end{array}$ & $\begin{array}{l}\text { Present at concentrations of } \\
0.3-1.5 \times 10^{10} \text { cells/g dry } \\
\text { human feces (Franks and } \\
\text { others, 1998) or } 8 \times 10^{10} \\
\text { cells/g wet human feces } \\
\text { (Marteau and others, } \\
\text { 2001). } \\
\text { Present in all } 20 \text { animals } \\
\text { tested; } \text { B. dentium and } B \text {. } \\
\text { adolescentis found in } 12 \\
\text { of } 12 \text { humans and } 22 \text { of } \\
22 \text { human waste streams } \\
\text { tested, and } B \text {. longum } \\
\text { found in } 7 \text { of } 12 \text { humans } \\
\text { tested (Bonjoch and oth- } \\
\text { ers, } 2004 \text { ). } \\
\text { Sorbitol-fermenting Bifido- } \\
\text { bacterium concentrations } \\
\text { range across } 3 \text { orders of } \\
\text { magnitude, where pres- } \\
\text { ent (Mara and Oragui, } \\
\text { 1983). }\end{array}$ & $\begin{array}{l}\text { Stable populations } \\
\text { indicated over } 4 \\
\text { weeks of moni- } \\
\text { toring } \\
\text { (Satokari and } \\
\text { others, 2001). }\end{array}$ & $\begin{array}{l}\text { Short survival time } \\
\text { in the environment } \\
\text { and very sensitive } \\
\text { to chlorination (in } \\
\text { Mara and Oragui, } \\
\text { 1983). }\end{array}$ & $\begin{array}{l}\text { No description of the } \\
\text { relation between } \\
\text { Bifidobacterium spp. } \\
\text { incidence or concen- } \\
\text { tration with regula- } \\
\text { tory fecal-indicator } \\
\text { microbe incidence } \\
\text { or concentration was } \\
\text { found. }\end{array}$ \\
\hline $\begin{array}{l}\text { Enterococcus } \\
\text { (adhesin } \\
\text { genes) }\end{array}$ & $\begin{array}{l}\text { Only found in human- } \\
\text { associated sewage } \\
\text { sources (Scott and } \\
\text { others, 2005). }\end{array}$ & $\begin{array}{l}\text { Found in } 94 \% \text { of human-as- } \\
\text { sociated sewage sources } \\
\text { (Scott and others, 2005). }\end{array}$ & $\begin{array}{l}\text { See entry for } \\
\text { Enterococcus } \\
\text { genotypes and } \\
\text { phenotypes. }\end{array}$ & $\begin{array}{l}\text { See entry for Entero- } \\
\text { coccus genotypes } \\
\text { and phenotypes. }\end{array}$ & $\begin{array}{l}\text { May be relevant to } \\
\text { enterococci-concentra- } \\
\text { tion-based regulations. }\end{array}$ \\
\hline $\begin{array}{l}\text { Enterococcus } \\
\text { (species) }\end{array}$ & $\begin{array}{l}\text { Differentially distrib- } \\
\text { uted among hosts } \\
\text { (Aarestrup and others, } \\
\text { 2000; Delahoya and } \\
\text { others, 2002). } \\
\text { Of } 61 \text { E. faecalis, } 30 \text { were } \\
\text { from humans and the } \\
\text { remainder from dogs } \\
\text { and chickens (Wheeler } \\
\text { and others, 2002). } \\
\text { Note that the number } \\
\text { of individuals sampled } \\
\text { was 2-3 per host. }\end{array}$ & $\begin{array}{l}\text { One of } 4 \text { human, } 1 \text { of } 2 \mathrm{dog} \text {, } \\
\text { and } 2 \text { of } 3 \text { chicken indi- } \\
\text { viduals sampled hosted } \\
\text { E. faecalis (Wheeler and } \\
\text { others, 2002). }\end{array}$ & $\begin{array}{l}\text { No report of the } \\
\text { timespan over } \\
\text { which various } \\
\text { Enterococcus } \\
\text { species persist or } \\
\text { variation in con- } \\
\text { centration within } \\
\text { individual hosts } \\
\text { was found. }\end{array}$ & $\begin{array}{l}\text { No report of the rela- } \\
\text { tive survival of vari- } \\
\text { ous Enterococcus } \\
\text { species was found. }\end{array}$ & $\begin{array}{l}\text { Indirectly relevant to } \\
\text { enterococci-concentra- } \\
\text { tion-based regulations. }\end{array}$ \\
\hline
\end{tabular}


Table 2

Table 2: Summary of how various microbial source tracking (MST) source identifiers meet generalized assumptions for application.Continued

[More extensive details are presented in the text]

\begin{tabular}{|c|c|c|c|c|c|}
\hline $\begin{array}{l}\text { Source } \\
\text { identifier }\end{array}$ & Host specificity & Distribution & Stability in host & $\begin{array}{c}\text { Stability (survival) in } \\
\text { environment }\end{array}$ & $\begin{array}{l}\text { Relevance to regula- } \\
\text { tions, health risk }\end{array}$ \\
\hline $\begin{array}{l}\text { Escherichia } \\
\text { coli } \\
\text { (genotypes } \\
\text { and pheno- } \\
\text { types) }\end{array}$ & $\begin{array}{l}\text { Same genotype found in } \\
\text { multiple hosts (Gordon, } \\
\text { 2001; McLellan and } \\
\text { others, 2003; Scott } \\
\text { and others, 2003); } \\
\text { about 10-20\% of types } \\
\text { (40-65\% of isolates) } \\
\text { shared among hosts } \\
\text { (Hartel and others, } \\
\text { 2002). } \\
\text { Gene transfer has been } \\
\text { demonstrated among } \\
\text { E. coli between host } \\
\text { species (Oppegaard and } \\
\text { others, 2001). }\end{array}$ & $\begin{array}{l}\text { Prevalent in mammals, } \\
\text { less prevalent in birds, } \\
\text { and uncommon in fish, } \\
\text { amphibians, and reptiles } \\
\text { (>1\% of cultivable } \\
\text { aerobic enteric bacteria; } \\
\text { Gordon and Cowling, } \\
\text { 2003). Found in areas } \\
\text { with no fecal contamina- } \\
\text { tion expected (Carrillo } \\
\text { and others, } 1985) \text {. } \\
\text { Genotype distribution is } \\
\text { minimally (1-10\%) } \\
\text { attributable to spatial } \\
\text { separation (Gordon, } \\
\text { 2001). } \\
\text { Concentrations can vary } \\
\text { by as much as } 6 \text { orders } \\
\text { of magnitude in specific } \\
\text { hosts ( } 1.9 \times 10^{3}-6.3 \times 10^{9} \\
\text { CFU/g wet wt poultry } \\
\text { dropping); geometric } \\
\text { mean concentrations } \\
\text { range from } 1.5 \times 10^{3} \text { in } \\
\text { horses to } 2.1 \times 10^{9} \mathrm{CFU} / \mathrm{g} \\
\text { wet feces in dogs (Mara } \\
\text { and Oragui, } 1983 \text { ). }\end{array}$ & $\begin{array}{l}\text { Genotypes are } \\
\text { temporally } \\
\text { unstable in the } \\
\text { host (Cooke and } \\
\text { others, 1969; } \\
\text { Gordon, 2001). } \\
\text { About half of E. coli } \\
\text { genotypes are } \\
\text { resident (stable) } \\
\text { and the remain- } \\
\text { der are transient } \\
\text { (unstable) in an } \\
\text { individual (Cau- } \\
\text { gant and others, } \\
\text { 1981; Whittam, } \\
\text { 1989). }\end{array}$ & $\begin{array}{l}\text { Different genotypes } \\
\text { detected in bird } \\
\text { feces and underlying } \\
\text { (aged) litter (Whit- } \\
\text { tam, 1989). } \\
\text { Not considered to have } \\
\text { survival strategies in } \\
\text { the environment as a } \\
\text { component of its life } \\
\text { cycle (Winfield and } \\
\text { Groisman, 2003). } \\
\text { Known to be stable in } \\
\text { tropical environ- } \\
\text { ments, though } \\
\text { thought to be unable } \\
\text { to reproduce in tem- } \\
\text { perate environments } \\
\text { (Rivera and others, } \\
\text { 1988; Winfield and } \\
\text { Groisman, 2003); } \\
\text { however, there exist } \\
\text { habitats in temperate } \\
\text { climates in which E. } \\
\text { coli can survive and } \\
\text { perhaps reproduce } \\
\text { (Whitman and Nev- } \\
\text { ers, 2003; Whitman } \\
\text { and others, 2003). }\end{array}$ & $\begin{array}{l}\text { One of two recommended } \\
\text { fecal indicator bacteria } \\
\text { for coastal recreational } \\
\text { waters (U.S. Congress, } \\
\text { 2000). }\end{array}$ \\
\hline
\end{tabular}


Table 2: Summary of how various microbial source tracking (MST) source identifiers meet generalized assumptions for application.Continued

[More extensive details are presented in the text]

\begin{tabular}{|c|c|c|c|c|c|}
\hline $\begin{array}{l}\text { Source } \\
\text { identifier }\end{array}$ & Host specificity & Distribution & Stability in host & $\begin{array}{c}\text { Stability (survival) in } \\
\text { environment }\end{array}$ & $\begin{array}{l}\text { Relevance to regula- } \\
\text { tions, health risk }\end{array}$ \\
\hline $\begin{array}{l}\text { E. coli } \\
\text { (toxin genes) }\end{array}$ & $\begin{array}{l}\text { The gene } l t \text {-IIa has been } \\
\text { found exclusively in } \\
\text { cattle (Pickett and } \\
\text { others, 1987); the gene } \\
s t \text {-II (pig associated) is } \\
\text { differentially distribut- } \\
\text { ed among several hosts } \\
\text { (Chern and others, } \\
\text { 2004); the gene slt-IIe } \\
\text { has been found in pigs } \\
\text { and humans (Franke } \\
\text { and others, 1995); the } \\
\text { gene st-Ib (human-as- } \\
\text { sociated) was detected } \\
\text { in } 8 \% \text { of non-human } \\
\text { individuals and } 9 \% \\
\text { of human individuals } \\
\text { (100\% of composite } \\
\text { human sources and } \\
25 \% \text { of composite non- } \\
\text { human sources; Field } \\
\text { and others, 2003) } \\
\text { Of three probes used to } \\
\text { detect toxin genes, de- } \\
\text { tection rate in alternate } \\
\text { sources was } 2 \text { of } 9 \text { (7\% } \\
\text { false detect; Field and } \\
\text { others, } 2003 \text { ) }\end{array}$ & $\begin{array}{l}\text { Fewer than } 1 \% \text { of } E \text {. coli } \\
\text { carry toxin genes in most } \\
\text { waste streams (Chern } \\
\text { and others, 2004). } \\
\text { Pathogenic E. coli are } \\
\text { absent from most healthy } \\
\text { individuals (Chern and } \\
\text { others, 2004; Gordon, } \\
\text { 2001). }\end{array}$ & $\begin{array}{l}\text { No report of the } \\
\text { timespan over } \\
\text { which pathogenic } \\
\text { E. coli persist or } \\
\text { variation in con- } \\
\text { centration within } \\
\text { individual hosts } \\
\text { was found. }\end{array}$ & $\begin{array}{l}\text { See entries for } E \text {. coli } \\
\text { genotypes and pheno- } \\
\text { types. }\end{array}$ & $\begin{array}{l}\text { Indirectly relevant to } E \text {. } \\
\text { coli-based regulations. } \\
\text { Directly related to } \\
\text { health risk for suscep- } \\
\text { tible animals }\end{array}$ \\
\hline
\end{tabular}


Table 2: Summary of how various microbial source tracking (MST) source identifiers meet generalized assumptions for application.Continued

[More extensive details are presented in the text]

\begin{tabular}{|c|c|c|c|c|c|}
\hline $\begin{array}{c}\text { Source } \\
\text { identifier }\end{array}$ & Host specificity & Distribution & Stability in host & $\begin{array}{c}\text { Stability (survival) in } \\
\text { environment }\end{array}$ & $\begin{array}{c}\text { Relevance to regula- } \\
\text { tions, health risk }\end{array}$ \\
\hline $\begin{array}{l}\text { Salmonella } \\
\text { enterica } \\
\text { serovar Ty- } \\
\text { phimurium }\end{array}$ & $\begin{array}{l}\text { Avian types more similar } \\
\text { to one another than } \\
\text { to those from other } \\
\text { hosts. Avian types can } \\
\text { colonize other hosts } \\
\text { and, specifically, cause } \\
\text { disease in humans } \\
\text { (Refsum and others, } \\
\text { 2002). }\end{array}$ & $\begin{array}{l}\text { No report of the distribu- } \\
\text { tion among various } \\
\text { hosts was found. }\end{array}$ & $\begin{array}{l}\text { No report of the timespan } \\
\text { over which Salmo- } \\
\text { nella enterica } \text { serovar } \\
\text { Typhimurium persists or } \\
\text { variation in concentra- } \\
\text { tion within individual } \\
\text { hosts was found. }\end{array}$ & $\begin{array}{l}\text { Considered to have survival } \\
\text { strategies in the environ- } \\
\text { ment as a component } \\
\text { of its life cycle, leading } \\
\text { to long survival under } \\
\text { adverse conditions }\left(\mathrm{t}_{50} \text { up }\right. \\
\text { to } 1 \text { year in soil; Winfield } \\
\text { and Groisman, 2003). }\end{array}$ & $\begin{array}{l}\text { Human outbreaks of } \\
\text { salmonellosis (in } \\
\text { Refsum and others, } \\
\text { 2002). }\end{array}$ \\
\hline \multicolumn{6}{|c|}{ 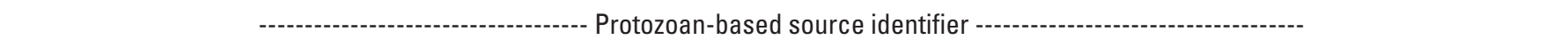 } \\
\hline $\begin{array}{l}\text { Cryptospo- } \\
\text { ridium } \\
\text { (species) }\end{array}$ & $\begin{array}{l}\text { C. parvum genotype I is } \\
\text { exclusive to humans, } \\
\text { type II readily transfers } \\
\text { between humans and } \\
\text { other mammals, and } \\
\text { various other host- } \\
\text { associated types oc- } \\
\text { casionally are detected } \\
\text { in humans (in Ong and } \\
\text { others, 2002). } \\
\text { Nine species other than C. } \\
\text { parvum are host associ- } \\
\text { ated but not exclusive } \\
\text { (Fayer and others, } \\
\text { 2000). } \\
\text { Only five genotypes of } \\
\text { Cryptosporidium spp. } \\
\text { are known to infect } \\
\text { humans (Xiao and oth- } \\
\text { ers, 2001). } \\
\text { Some populations appear } \\
\text { to be host-specific, but } \\
\text { others move between } \\
\text { host species (Mallon } \\
\text { and others, 2003). }\end{array}$ & $\begin{array}{l}\text { Incidence in fresh } \\
\text { livestock waste ranged } \\
\text { from 5\% (cattle) to } \\
29 \% \text { (sheep; Hutchison } \\
\text { and others, 2004). } \\
\text { C. parvum detected in } \\
\text { 1\% of wildlife (6 of } 19 \\
\text { species), 5\% of sewage } \\
\text { influent samples, and } \\
\text { 4\% of agricultural } \\
\text { waste (Heitman and } \\
\text { others, 2002). } \\
\text { Detected in } 4 \% \text { of cattle } \\
\text { (Atwill and others, } \\
\text { 1999). } \\
\text { C. parvum detected in } \\
\text { 13-22\% of rodents; } \\
\text { C. muris detected in } \\
\text { 2-10\% of rodents } \\
\text { (Chalmers and others, } \\
\text { 1997). } \\
\text { C. parvum detected in } \\
\text { 12\% of wild mammals } \\
\text { (Sturdee and others, } \\
\text { 1999). } \\
\text { Over 100 species have } \\
\text { been reported infected } \\
\text { with C. parvum and } \\
\text { C. parvum-like strains } \\
\text { (Fayer and others, } \\
\text { 2000). } \\
\text { (Fand }\end{array}$ & $\begin{array}{l}\text { Known to pass through and } \\
\text { be transmitted by various } \\
\text { hosts (Fayer and others, } \\
\text { 2000). }\end{array}$ & $\begin{array}{l}\text { Can remain viable for } \\
\text { greater than } 6 \text { months } \\
\text { at } 20 \text { degrees Celsius in } \\
\text { water (Fayer and others, } \\
2000 . \\
\text { In three environmental fresh } \\
\text { waters, } 0.1 \% \text { survival } \\
\text { over } 10 \text { weeks at } 25 \text { de- } \\
\text { grees and higher rates } \\
\text { of survival at } 4 \text { degrees } \\
\text { (Simmons and Sobsey, } \\
\text { 2002). } \\
\text { Survival and infectivity in } \\
\text { freshwater detected after } \\
\text { more than } 12 \text { weeks (Ol- } \\
\text { son and others 1999). }\end{array}$ & $\begin{array}{l}\text { Pathogenic agent of } \\
\text { cryptosporidiosis, } \\
\text { caused 50\% of re- } \\
\text { ported gastroenteritis } \\
\text { cases due to consump- } \\
\text { tion of treated water } \\
\text { in 2001-02 (Yoder } \\
\text { and others, 2004). }\end{array}$ \\
\hline
\end{tabular}

